\author{
Jr brig. Piotr Lesiak, M.Sc. Eng. ${ }^{\text {a)*; }}$ brig. Damian Bąk, Eng. .a); brig. Daniel Małozięć, M.Sc. Eng. . ${ }^{a)}$; \\ Marcin Grabarczyk, Ph.D.); Andrzej Kołaczkowski, M.Sc. Eng. ${ }^{\text {) }}$
}

\author{
a) Scientific and Research Centre for Fire Protection-National Research Institute / Centrum Naukowo-Badawcze Ochrony \\ Przeciwpożarowej im. Józefa Tuliszkowskiego - Państwowy Instytut Badawczy \\ b) NASK - Research and Academic Computer Network - National Research Institute / Naukowa i Akademicka Sieć Komputerowa \\ Państwowy Instytut Badawczy \\ c) "Anko" Przedsiębiorstwo Produkcyjno-Usługowe Andrzej Kołaczkowski \\ * Corresponding author / Autor korespondencyjny: plesiak@cnbop.pl
}

\title{
Evaluation of the Effectiveness of Active HRD Systems for Dust Explosion Suppression in a Technology Demonstrator System
}

\author{
Ocena skuteczności tłumienia wybuchu pyłowego w układzie demonstratora \\ przez aktywny system HRD
}

\begin{abstract}
Purpose: This paper presents the operation of an active dust explosion (HRD, high rate discharge) suppression system in a confined space. Design and methods: The study involved tests of the developed fire protection system for suppressing dust explosions. The work was carried out under the project entitled "Innovative explosion protection technologies, including for highly protected facilities" No. DOBR-BIO4/052/13073/2013 at the Scientific and Research Centre for Fire Protection in Józefów.

A test station designed and constructed to meet the prerequisites of the PN-EN 14034 series of standards was designed for testing. The test equipment consisted of a closed roughly spherical chamber with a volume of $1 \mathrm{~m}^{3}$, an ignition system, a system producing a dust-air atmosphere, and a pressure change detection system. Inside the sphere, a dust-air mixture of a certain concentration was obtained in a reproducible manner. The station was armed with a dust explosion suppression system consisting of:

$-5 \mathrm{dm}^{3}$ fire extinguisher tank containing pressurized fire-extinguishing powder,

- a diffusing nozzle,

- an explosion detection system.

The operation of the extinguishing system is based on the early detection of changes in the explosion pressure of the dust-air mixture, the processing of the signal, and the release of the extinguishing agent inside the apparatus in order to interrupt the explosion process at the earliest possible stage of its development.

Results: On the basis of the conducted experiments, it can be concluded that the HRD system effectively interrupts explosive combustion for dust with $\mathrm{a} \mathrm{K}_{\mathrm{st}} \leq 100 \mathrm{bar} \cdot \mathrm{m} / \mathrm{s}$. For the examined potato starch dust, the system significantly reduced the explosion pressure to an acceptable value. The system is also characterised by a short reaction time, and the discharge of the extinguishing powder takes place in less than $100 \mathrm{~ms}$, which is a satisfactory value. Conclusions: The tests were carried out for potato starch and lycopodium. The phenomenon of explosive combustion occurring in the mixture of lycopodium and air is characterised by greater dynamics, compared to starch. This difference allowed to identify the limitation of extinguishing dust explosions in small cubic capacity areas. In addition, research identified issues related to the source of ignition in the form of pyrotechnical heads, the use of which requires the setting of a high-pressure threshold activating the HRD system. This results in a delayed system reaction in the event of ignition of high $K_{s t}$ dust mixtures.

Keywords: HRD, explosion suppression system, dust explosion

Type of article: original scientific article
\end{abstract}

Received: 20.02.2019; Reviewed: 17.05.2019; Accepted: 28.06.2019;

Authors ORCID IDs: P. Lesiak - 0000-0001-8465-2169; D. Bąk - 0000-0002-4438-358X; D. Małozięć - 0000-0003-4929-8656;

M. Grabarczyk - 0000-0002-9996-0831; A. Kołaczkowski - 0000-0002-3722-3262;

Percentage contribution: P. Lesiak - 35\%; D. Bąk - 30\%; D. Małozięć 10\%; M. Grabarczyk - 10\%; A. Kołaczkowski - 15\%;

Please cite as: SFT Vol. 53 Issue 1, 2019, pp. 46-66, https://doi.org/10.12845/sft.53.1.2019.3;

This is an open access article under the CC BY-SA 4.0 license (https://creativecommons.org/licenses/by-sa/4.0/). 


\section{ABSTRAKT}

Cel: Celem artykułu jest przedstawienie działania aktywnego systemu tłumienia wybuchów pyłowych (nazwanych HRD od ang. high rate discharge) w przestrzeni ograniczonej.

Projekt i metody: W ramach badań przeprowadzono testy wytworzonego systemu gaśniczego do tłumienia wybuchów pyłowych. Prace zostały wykonane w ramach projektu pt. „Innowacyjne technologie zabezpieczeń przed wybuchem, w tym obiektów szczególnie chronionych” nr D0BR-BI04/052/13073/2013 w Centrum Naukowo-Badawczym Ochrony Przeciwpożarowej w Józefowie.

Do badań zaprojektowano i wykonano stanowisko spełniające założenia serii norm PN-EN 14034. Urządzenie badawcze składa się z zamkniętej komory kształtem zbliżonej do kuli o objętości $1 \mathrm{~m}^{3}$ oraz układów: zapłonowego, tworzenia atmosfery pyłowo-powietrznej, detekcji zmian ciśnienia. Wewnątrz sfery uzyskiwano w powtarzalny sposób mieszaninę pyłowo-powietrzną o określonym stężeniu. Stanowisko uzbrojono w system tłumienia wybuchów pyłowych zawierający:

- zbiornik gaśnicy o objętości 5 dm³ zawierający proszek gaśniczy pod ciśnieniem,

- dyszę rozpraszającą,

- system wykrywania wybuchu.

Działanie systemu gaśniczego opiera się na wczesnym wykryciu zmiany ciśnienia wybuchu mieszaniny pyłowo-powietrznej, przetworzeniu sygnału oraz wyzwoleniu środka gaśniczego do wnętrza aparatu w celu przerwania procesu wybuchu w jak najwcześniejszej fazie jego rozwoju.

Wyniki: Na podstawie przeprowadzonych eksperymentów można stwierdzić, że system HRD skutecznie przerywa spalanie wybuchowe dla pyłu o $\mathrm{K}_{\mathrm{st}} \leq 100 \mathrm{bar} \cdot \mathrm{m} / \mathrm{s}$. Dla przebadanego pyłu skrobi ziemniaczanej system znacznie redukuje ciśnienie wybuchu do wartości akceptowalnej. Układ charakteryzuje się także krótkim czasem reakcji, a wyładowanie proszku gaśniczego następuje w czasie poniżej 100 ms, co jest wartością satysfakcjonującą. Wnioski: Badania przeprowadzono dla skrobi ziemniaczanej i likopodium. Zjawisko spalania wybuchowego zachodzące w mieszaninie likopodium i powietrza charakteryzuje się większą dynamiką niż w przypadku skrobi. Różnica ta pozwoliła na zidentyfikowanie ograniczenia, jakim jest gaszenie wybuchów pyłowych w niewielkiej kubaturze. Ponadto w badaniach zidentyfikowano problematykę związaną z zastosowanym źródłem zapłonu w postaci główek pirotechnicznych, których zastosowanie narzuca konieczność nastawienia wysokiego progu ciśnienia aktywującego system HRD. Skutkuje to opóźnioną reakcją systemu w przypadku zapłonu mieszanin pyłowych o wysokiej wartości parametru $K_{\text {st. }}$.

Słowa kluczowe: HRD, system tłumienia wybuchu, wybuch pyłu

Typ artykułu: oryginalny artykuł naukowy

Przyjęty: 20.02.2019; Zrecenzowany: 17.05.2019; Zatwierdzony: 28.06.2019;

Identyfikatory ORCID autorów: P. Lesiak - 0000-0001-8465-2169; D. Bąk - 0000-0002-4438-358X; D. Małozięć - 0000-0003-4929-8656;

M. Grabarczyk - 0000-0002-9996-0831; A. Kołaczkowski-0000-0002-3722-3262;

Procentowy wkład merytoryczny: P. Lesiak - 35\%; D. Bąk - 30\%; D. Małozięć 10\%; M. Grabarczyk - 10\%; A. Kołaczkowski - 15\%;

Proszę cytować: SFT Vol. 53 Issue 1, 2019, pp. 46-66, https://doi.org/10.12845/sft.53.1.2019.3;

Artykuł udostępniany na licencji CC BY-SA 4.0 (https://creativecommons.org/licenses/by-sa/4.0/)

\section{Background}

Industry has developed in parallel to process safety engineering, a discipline of which is broadly understood explosion protection. Undesired events, which often lead to failures generating dust-air explosions with significant consequences, have confirmed that this type of threat can occur at various stages of the industrial process. Unfortunately, substantial losses had to be suffered, not only in material terms, to gain this experience. Due to this, analysing combustion-related phenomena and studying explosive parameters has become an absolute necessity.

The basic explosion protection measures are divided into preventive and active. The former involve activities aimed at preventing the occurrence of explosive atmospheres and explosion initiation. The latter are carried out using technical devices which reduce or limit the effects of explosions. The difference between these protection measures lies in the presence, or lack, of the explosion. Preventive measures include all activities leading to eliminating explosive atmospheres, i.e. maintaining a concentration of the substance outside of its flammable

\section{Wprowadzenie}

Rozwój przemysłu przebiegał równolegle do rozwoju inżynierii bezpieczeństwa procesowego, do której zaliczamy także szeroko rozumianą ochronę przeciwwybuchową. Zdarzenia niepożądane, często kończące się poważnymi awariami w postaci wybuchów pyłowo-powietrznych potwierdziły, że zagrożenie tego typu może wystąpić na różnych etapach procesu przemysłowego. Niestety, zdobyte doświadczenie zostało okupione stratami o charakterze nie tylko materialnym. W związku z tym analiza zjawisk towarzyszących spalaniu oraz badania nad parametrami wybuchowości są dzisiaj absolutną koniecznością.

Podstawowe środki ochrony przeciwwybuchowej dzieli się na prewencyjne oraz czynne. Pierwsze z nich to działania mające zapobiegać tworzeniu się atmosfer wybuchowych i inicjacji wybuchu. Te drugie realizowane są poprzez urządzenia techniczne zmniejszające lub ograniczające skutki wybuchów. Różnica pomiędzy wymienionymi środkami ochrony sprowadza się zatem do obecności zjawiska wybuchu. Do metod prewencji należy zaliczyć wszystkie działania prowadzące do wyeliminowania atmosfer wybuchowych, tj. utrzymanie stężenia substancji poza 
range, reducing oxygen concentration in the oxidising medium, and eliminating the potential sources of ignition (mechanical, electrostatic, and other).

There is a fixed but ungrounded belief among engineers and process safety specialists that the installation of explosionprotection equipment is the definitive security measure for all threats. However, some industrial processes can only occur in the presence of explosive atmospheres. This is not only due to the economy of the process, but also the physical and chemical properties of the substances used. The technological implementations of explosion-protection methods are conventionally divided into passive and active systems. The former do not require triggering detectors, such as pressure sensors, ionisation gauges, thermocouples or photodiodes. An example of such a system could be an explosion venting device placed on the filtration system. It is designed in such a way that in the case of an excessive increase in pressure over the nominal operating pressure, it is torn open and directs the explosion effects (blast wave, flame, fragmented material) into a safe area.

This paper discusses tests of an active explosion suppression system. This technology is based on the appropriate (in terms of intensity) dosage of the right type of extinguishing agent to the protected area of a process line This solution involves preventing a situation in which the explosion reaches a pressure that exceeds the threshold device resistance. HRD systems protect structures from mechanical damage and internal fires which could lead to serious damage or further propagation of the undesirable event to other areas of the system.

The combination of extinguishing agents and active explosion suppression is a relatively new solution, as its first implementations date back to the 1960s. Merging these two concepts into a single technical solution, i.e. an extinguishing and suppressing device to control the combustion process, is even newer. Currently, researchers agree that HRD system performance should be assessed in terms of its effectiveness in inerting the combustible mixture (interruption of the previously initiated chemical reactions) of an explosive nature and the time of response to such hazards. Unfortunately, there is a problem with the unification of research methods that would verify the correctness of operation of the discussed systems. The authors of this paper present a review of literature on research and implementation work on HRD systems, as well as the results of their own design and experimental work.

\section{Literature review}

The amount of information available on HRD systems is limited. This is probably due to business competition issues and the unavailability on the market of alternative solutions providing similar or better effectiveness in suppressing explosions. These systems are a highly profitable product for manufacturers jej zakresem palności, zmniejszanie stężenia tlenu w medium utleniającym oraz eliminowanie potencjalnych źródeł zapłonu (mechanicznych, elektrostatycznych i innych).

Wśród inżynierów i specjalistów ds. bezpieczeństwa procesowego obserwuje się utrwalenie nieuzasadnionego przekonania, że montaż urządzeń zabezpieczających przed skutkami wybuchu stanowi panaceum na wszystkie zagrożenia. Tymczasem, niektóre procesy przemysłowe muszą się odbywać w obecności atmosfer wybuchowych. Jest to podyktowane nie tylko ich ekonomiką, lecz także właściwościami fizykochemicznymi stosowanych substancji. Technologiczne implementacje czynnych metod ochrony przeciwwybuchowej dzieli się umownie na systemy pasywne i aktywne. Pierwsze z wyżej wymienionych nie wykazują konieczności stosowania detektorów wyzwalających, takich jak czujniki ciśnienia, sondy jonizacyjne, termopary czy fotodiody. Przykładem takiego systemu może być membrana odciążająca umieszczona na zespole filtracyjnym. Jest ona zaprojektowana tak, aby w przypadku wystąpienia zjawiska skutkującego np. nadmiernym przyrostem ciśnienia ponad nominalne ciśnienie pracy, nastąpiło jej rozerwanie i ukierunkowanie skutków wybuchu (fala ciśnienia, płomień, fragmenty materiału) w bezpieczny obszar.

Niniejszy artykuł poświęcony jest testom aktywnego systemu ochrony przeciwwybuchowej. Działanie technologii polega na właściwym (pod względem intensywności) podaniu odpowiedniego rodzaju środka gaśniczego do chronionej części układu technologicznego. Idea tego rozwiązania polega na uniemożliwieniu wystąpienia sytuacji, w której wybuch osiąga ciśnienie przekraczające graniczną wytrzymałość zabezpieczanego urządzenia. Systemy HRD chronią konstrukcje przed uszkodzeniami mechanicznymi oraz pożarami wewnętrznymi mogącymi doprowadzić do poważnych zniszczeń lub dalszej propagacji zjawiska niepożądanego na inne obszary instalacji.

Połączenie środków gaśniczych oraz czynnej ochrony przeciwwybuchowej to rozwiązanie stosunkowo nowe, ponieważ pierwsze wdrożenia datuje się na lata 60. ubiegłego wieku. Fuzja tych dwóch zagadnień w jedno techniczne rozwiązanie, czyli urządzenie gasząco-tłumiące niekontrolowane zjawisko spalania to próby jeszcze nowsze. Obecnie badacze zdają się być zgodni, że działanie systemów HRD należy oceniać pod względem ich skuteczności w inertyzacji mieszaniny palnej (przerwaniu zainicjowanych już reakcji chemicznych) o charakterze wybuchu oraz czasu reakcji na takie zagrożenie. Problem stanowi niestety unifikacja metod badawczych, które weryfikowałyby poprawność działania omawianych systemów. W niniejszym artykule autorzy prezentują przegląd literatury dotyczących prac badawczych i wdrożeniowych nad systemami HRD, a także wyniki własnych prac o charakterze konstrukcyjno-eksperymentalnym.

\section{Przegląd literatury}

llość dostępnych informacji na temat systemów HRD jest niestety ograniczona. Jest to prawdopodobnie związane m.in. z kwestiami konkurencji biznesowej oraz niedostępnością na rynku innych rozwiązań zapewniających zbliżoną lub lepszą skuteczność tłumienia wybuchów. Systemy stanowią dochodo- 
of explosion suppression solutions. The technological advantage achieved in this field translates into the market situation of the manufacturers. Information on the discussed solutions is usually available in scientific databases, but fragmented and incomplete. Specialised publications involving studies on HRD systems in English can be found using such keywords as explosion suppressants and explosion suppression, sometimes also fire-extinguishing agents, but only in combination with gas/dust explosions. The following is an overview of the publicly available papers which the authors consider to be the most relevant.

Moore [1] presented the detailed requirements regarding fireextinguishing agents that could act as explosion suppressants. In his research, he concentrated on halons, water and powders. For each of these agents, he defined their effective extinguishing concentration. Taveua et al. [2] studied the suppression of aluminium dust explosions in several test reactors with volumes of $1 \mathrm{~m}^{3}$ and $4.4 \mathrm{~m}^{3}$ using two suppressants produced by Fike Corporation labelled PK and SBC. Statistical studies show that the deflagration of metal dusts is a phenomenon occurring almost regularly in various branches of industry and HRD systems seem to be the only effective method of minimising their effects. The conducted studies lead to various conclusions, depending on the scale of the studied phenomenon. For deflagration index Kst lower than 300 bar $\cdot \mathrm{m} / \mathrm{s}$ in a volume of $1 \mathrm{~m}^{3}$ - with the application of an appropriately low activation threshold for the HRD system and correct selection of suppressant concentration - it was possible to reduce the pressure to 1 bar. For the volume of $4.4 \mathrm{~m}^{3}$, the reduction of deflagration was possible only if its index did not exceed $200 \mathrm{bar} \cdot \mathrm{m} / \mathrm{s}$, also with a correct system configuration. Concentrations of aluminium dust higher than $500 \mathrm{~g} / \mathrm{m}^{3}$ are not found in industrial processes. Taveua et al. [2] think that HRD systems can be used to protect such industrial elements as flow-through air purifiers. In addition, the authors suggest that for higher aluminium dust concentrations a set of smaller HRD systems should be used instead of one, which would reduce the release time and minimise the distance over which the suppressant can be distributed. Another interesting aspect of the paper is the discussion on combining HRD systems with decompression systems.

Sun et al. [3] tested the potential for suppressing the explosions of methane-air mixtures using a new agent based on kaolinite, i.e. a silicate clay mineral. The tests were carried out using a 20-litre spherical reactor and covered various aspects of the extinguishing processes, including chemical and physical. According to the authors, the addition of porous materials to fire-extinguishing powders increases the area in which inhibitors can absorb free radicals. The tests were conducted in three stages, assessing the impact on explosion pressure of the following factors - combustible dust concentration, kaolinite concentration and the choice of powder that can be combined with kaolinite.

Experimental studies are accompanied by numerical tests conducted involving CFD, i.e. computational fluid dynamics. Song \& Zhang [4] carried out tests involving an attempt to suppress the detonation of methane-air mixtures inside a pipe using water mist. They used $k-\varepsilon$ turbulence models and modelled wy produkt z punktu widzenia dostawców rozwiązań ochrony przeciwwybuchowej. Uzyskana przewaga technologiczna w tym obszarze przekłada się zatem na pozycję rynkową producentów. Informacje dotyczące przedmiotowych rozwiązań dostępne są zazwyczaj pośrednio w naukowych bazach danych, przedstawione w sposób fragmentaryczny oraz niekompletny. Specjalistycznych publikacji na temat badań nad systemami typu HRD w anglojęzycznym piśmiennictwie należy szukać za pomocą takich słów kluczowych, jak explosion suppressants oraz explosion suppresion, czasem także fire-extinguishing agents, ale jedynie w połączeniu z gas/dust explosions. Poniżej zaprezentowany został skrót najciekawszych - zdaniem autorów - prac, których wyniki są powszechnie dostępne.

Moore [1] przedstawił szczegółowe wymagania dotyczące środków gaśniczych mogących stanowić czynnik tłumiący wybuchy. W swoich badaniach skupił się na halonach i wodzie oraz na proszkach. Dla każdego z tych środków określił efektywne stężenie gaszące. Taveua i inni [2] przeprowadzili badania tłumienia wybuchów pyłu aluminium w kilku reaktorach badawczych o objętościach $1 \mathrm{~m}^{3}$ oraz 4,4 $\mathrm{m}^{3} \mathrm{z}$ użyciem dwóch środków tłumiących marki Fike Corporation o oznaczeniach PK i SBC. Z badań statystycznych wynika, że deflagracyjne spalanie pyłów metali to zjawisko występujące niemal regularnie w różnych gałęziach przemysłu, a systemy HRD wydają się jedyną skuteczną metodą minimalizacji ich skutków. Przeprowadzone badania można skonkludować $w$ różny sposób, w zależności od skali badanego zjawiska. Dla indeksów deflagracji $\mathrm{K}_{\mathrm{st}}$ mniejszych niż $300 \mathrm{bar} \cdot \mathrm{m} / \mathrm{s}$ w objętości $1 \mathrm{~m}^{3}$ - przy zastosowaniu odpowiednio niskiego progu aktywacji systemu HRD i prawidłowego doboru stężenia środka tłumiącego - możliwe było zredukowanie ciśnienia do 1 bar. Z kolei dla objętości 4,4 $\mathrm{m}^{3}$ ograniczenie zjawiska deflagracji było możliwe jedynie, jeżeli jego indeks nie przekroczył $200 \mathrm{bar} \cdot \mathrm{m} / \mathrm{s}$, również przy właściwej konfiguracji systemu. Dla pyłu aluminium w procesach przemysłowych nie spotyka się stężeń wyższych niż $500 \mathrm{~g} / \mathrm{m}^{3}$. Taveua i inni [2] uważają, że systemami HRD można zabezpieczać takie elementy przemysłowe, jak przepływowe oczyszczacze powietrza. Dodatkowo, autorzy postulują, aby dla wyższych stężeń pyłu aluminium zastosować zamiast jednego systemu HRD dużej skali układ kilku mniejszych, skracając tym samym czas wyładowania oraz minimalizując dystans, na którym możliwe jest rozproszenie czynnika tłumiącego. Ciekawy aspekt artykułu to również dyskusja nad połączeniem systemów typu HRD z systemami dekompresji.

Sun i inni [3] sprawdzali możliwość tłumienia wybuchów mieszanin metan-powietrze za pomocą nowego czynnika na bazie kaolinitu, tj. minerału z gromady krzemianów ilastych. Badania przeprowadzone zostały przy użyciu 20-litrowego sferycznego reaktora i objęły różne aspekty procesów gaszenia, zarówno chemiczne, jak i fizyczne. Zdaniem autorów, wzbogacenie proszków gaśniczych materiałami o strukturze porowatej zwiększy powierzchnię wchłaniania wolnych rodników przez inhibitory. Badania przeprowadzono w trzech etapach i oceniono w nich, jaki wpływ na ciśnienie wybuchu mają kolejnych czynników: stężenia pyłu palnego, stężenia kaolinitu oraz doboru proszku współdziałającego z kaolinitem. 
water mist using a discrete phase model. They conducted the calculations for spray nozzle outputs $0.3-1.5 \mathrm{~kg} / \mathrm{m}^{3}$ of water for drops with a constant diameter of $50-150 \mu \mathrm{m}$. A comparison of the calculation results and experimental studies yielded very good results. This leads to the conclusion that despite the adopted simplifications, i.e. selected models and method of space discretisation (the computational grid and analysis of a two-dimensional case), it is possible to model the occurring phenomena with a significant degree of precision. Song \& Zhang suggest that the chemical reaction was slowed down as a result of the water receiving heat from the reaction area with a simultaneous energy-intensive phase transition. For water mist drops with other-than-specified diameters, the extinguishing effectiveness is reduced, which is consistent with the theoretical model cited by the authors.

Using CFD techniques would not be possible without deriving the analytical dependences describing flow mechanics with a chemical reaction. An attempt to mathematically model the suppression of explosions of dust-air mixtures was made by Oleszczak and Klemens [5]. The generalised description of the exchange of mass, momentum and energy between the gaseous and liquid phases, as suggested by these authors, can be considered particularly valuable. It was obtained by adding relevant expressions describing the transfer of the said physical quantities in non-stationary processes to the Navier-Stokes equations.

More information on explosion suppression (for both gas and dust) can be found in review articles, which collect and systematise the results of studies on process safety engineering. One very good and extensive review is the one written by Wang et al. [6]. The introduction contains basic information about explosiveness, detonation, and the DDT (deflagration-todetonation transition) phenomenon. The individual chapters are dedicated to the passive and active suppression methods and the total number of papers and scientific reports analysed for the purposes of this work exceeds 60 .

Active explosion suppression systems were also the subject of analyses by scientists from the Warsaw University of Technology [7]. As a result of the implementation work on HRD systems, i.a., an assessment was carried out of the medium carrying the fire extinguishing agent from its tank to the protected area where the explosion was developing.

Continuing their work on a fire extinguishing system, $\mathrm{Kl}$ emens et al. [8] extended their research to include an analysis of the impact of operating conditions on suppression effectiveness, including the possibility that the fire extinguishing powder could aggregate in tanks as a result of the system vibrations. In another paper, Gieras et al. [9] assessed the effectiveness of the HRD system in terms of interrupting the combustion process of a corn starch-air mixture and a methane-air mixture. The chamber used in their study had a volume of $1.3 \mathrm{~m}^{3}$.
Obok badań eksperymentalnych prowadzone są także prace o charakterze numerycznym z wykorzystaniem technik CFD, tj. obliczeniowej mechaniki płynów. Song i Zhang [4] wykonali badania obejmujące próbę tłumienia detonacji mieszanin metan-powietrze w rurze za pomocą mgły wodnej. Użyli oni modelu turbulencji k- $\varepsilon$, natomiast mgłę wodną zamodelowali za pomocą modelu fazy dyskretyzowanej. Obliczenia przeprowadzili dla wydatków rozpylaczy z zakresu $0,3-1,5 \mathrm{~kg} / \mathrm{m}^{3}$ wody dla kropli o stałej średnicy z zakresu 50-150 $\mu \mathrm{m}$. Porównanie wyników obliczeń z badaniami eksperymentalnymi dało bardzo dobre rezultaty. Utwierdziło to badaczy w przekonaniu, że pomimo przyjętych uproszczeń, tj. dobranych modeli i sposobu dyskretyzacji przestrzeni (siatka obliczeniowa i rozważanie przypadku dwuwymiarowego), możliwe jest całkiem dokładne zamodelowanie zachodzących zjawisk. Song i Zhang postulują, że spowolnienie reakcji chemicznej następuje w wyniku odebrania przez wodę ciepła ze strefy reakcji przy jednoczesnej, energochłonnej, przemianie fazowej. Dla kropel mgły wodnej o średnicy spoza ww. zakresu, skuteczność gaszenia słabnie, co jest zgodne z przytoczonym przez badaczy modelem teoretycznym rozważanych zjawisk.

Wykorzystanie technik CFD nie byłoby możliwe bez wyprowadzenia analitycznych zależności opisujących mechanikę przepływu z reakcją chemiczną. Próbę matematycznego zamodelowania procesu tłumienia wybuchów mieszanin pyłowo-powietrznych podjęli Oleszczak i Klemens [5]. Za szczególnie wartościowy należy uznać zaproponowany przez badaczy uogólniony opis wymiany masy, pędu oraz energii pomiędzy fazą gazową a ciekłą. Dokonano tego poprzez dodanie do równania Naviera-Stokesa odpowiednich wyrazów opisujących transfer wyżej wymienionych wielkości fizycznych w procesach niestacjonarnych.

Więcej informacji w obszarze tłumienia detonacji (zarówno gazowych, jak i pyłowych) można znaleźć w artykułach przeglądowych, w których zebrano i usystematyzowano wyniki badań dotyczących inżynierii bezpieczeństwa procesowego. Bardzo dobrym i szerokim opracowaniem, zdaniem autorów, jest to napisane przez Wanga i innych [6]. We wstępie zawarte zostało wprowadzenie do tematyki wybuchowości, detonacji oraz zjawiska DDT. Pasywnym i aktywnym metodom tłumienia poświęcone są odpowiednio oddzielne rozdziały, a łączna liczba przeanalizowanych na poczet omawianej pracy artykułów i doniesień naukowych przekracza 60.

Aktywne systemy tłumienia wybuchu były także przedmiotem analiz badaczy z Politechniki Warszawskiej [7]. W wyniku prac wdrożeniowych systemów HRD dokonano m.in. oceny medium niosącego środek gaśniczy z jego zasobnika do obszaru chronionego, w którym rozwijał się wybuch.

Kontynuując prace nad swoim systemem gaśniczym, Klemens i inni [8] rozszerzyli badania o analizę wpływu warunków jego eksploatacji na skuteczność tłumienia, w tym możliwość agregacji proszku gaśniczego w zbiornikach wskutek drgań instalacji. W innej pracy Gieras i inni [9] dokonali oceny skuteczności systemu HRD pod kątem przerwania procesu spalania mieszaniny skrobi kukurydzianej i powietrza oraz metanu i powietrza. Użyta przez nich komora miała objętości 1,3 $\mathrm{m}^{3}$. 


\section{Methods}

After about $30-100 \mathrm{~ms}$ from the time of ignition in an explosion of the dust-air mixture, the pressure reaches its maximum value (expressed as $P_{\max }$ ) in a given closed volume. The basic concept behind the suppression systems involves:

- detecting rapidly-increasing pressure inside a protected volume

- launching the extinguishing system.

Figure 1 presents a schematic diagram.

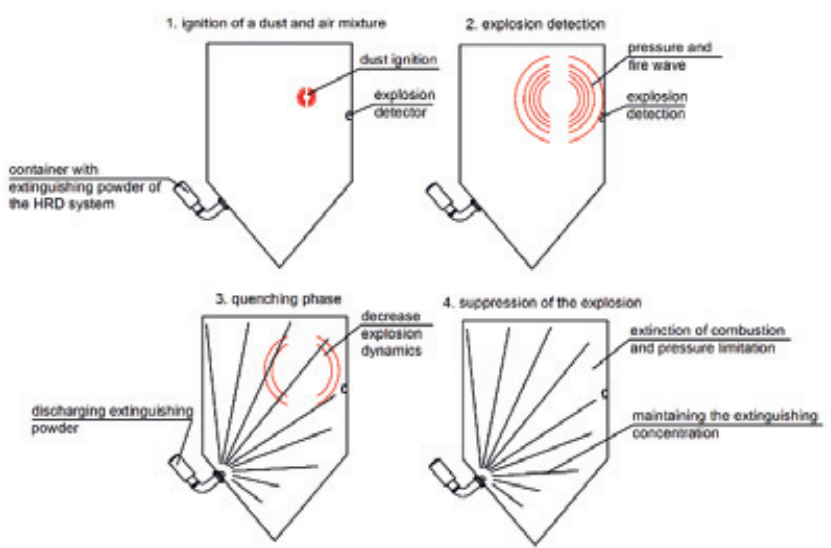

Figure 1. The principle of the HRD explosion suppression system Rycina 1. Zasada działania systemu tłumiącego wybuch HRD Source: Own elaboration.

Źródło: Opracowanie własne.

Explosion suppression systems are usually deployed in areas where other solutions, such as the release of explosion pressure cannot be used due to the location of the technological apparatus or other circumstances specified in the risk assessment. It is sometimes possible (and used in practice) to combine explosion venting and explosion suppression systems. Such combinations respond to cases in which it is impossible to use an adequately high venting volume (size limitations), or when it is necessary to reduce the so-called impact of flame, which is released into the venting space.

In practice, suppression systems are used to protect equipment with a wide variety of volumes from $0.25 \mathrm{~m}^{3}$ up to $1000 \mathrm{~m}^{3}$. Suppression systems ensure the safe extinguishing of dust explosions in the St1 and St2 explosion classes. It is also possible to protect St3 dust-air mixtures (highly explosive) against explosions. However, these systems are limited to a narrow range of values of suppressed pressures.

In non-protected closed volumes, the pressure accompanying the explosion increases in accordance with the curve (fig. 2 - unsuppressed pressure). In a typical explosion of the dust-air mixture, the pressure might reach 10 bar. Such a pressure is too high for most standard process equipment. For ex-

\section{Metody}

Ciśnienie podczas wybuchu mieszaniny pyłowo-powietrznej po ok. 30-100 ms od momentu zapłonu osiąga wartość maksymalną (ozn. $P_{\text {max }}$ ) w danej objętości zamkniętej. Podstawowa idea działania systemów tłumiących wybuchy polega na:

- wykryciu dynamicznie wzrastającego ciśnienia wewnątrz zabezpieczanej kubatury,

- uruchomieniu systemu gaszącego.

Ideowy schemat działania przedstawiono na rycinie 1.

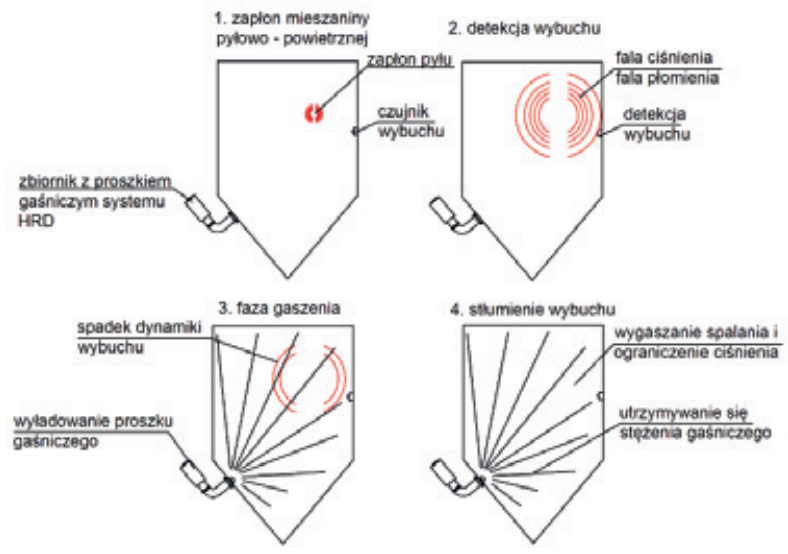

Systemy tłumienia wybuchów używane są zwykle w obszarach, w których nie udaje się zastosować innego typu rozwiązania, np. odprowadzenia ciśnienia wybuchu ze względu na lokalizację aparatu technologicznego lub inne okoliczności określone w wykonanej ocenie ryzyka. Niekiedy możliwe (i używane w praktyce) jest łączenie systemów odciążających z systemami tłumiącymi wybuch. Kombinacje takie są odpowiedzią na przypadki, w których niemożliwe jest użycie dostatecznie dużej objętości odciążającej (ograniczenia wymiarowe), bądź gdy konieczne jest zmniejszenie tzw. efektu oddziaływania płomienia, który uwalniany jest do przestrzeni odciążającej.

W praktyce systemy tłumienia stosowane są do zabezpieczenia urządzeń w szerokim zakresie objętości od $0,25 \mathrm{~m}^{3}$ aż do $1000 \mathrm{~m}^{3}$. Systemy tłumiące zapewniają bezpieczne wygaszenie wybuchu pyłów w klasach wybuchowości St1 oraz St2. Możliwa jest również ochrona przed wybuchem mieszanin pyłowopowietrznych klasy St3 (silnie wybuchowych), jednakże działanie tych systemów ograniczone jest do wąskiego przedziału wartości tłumionych ciśnień.

W niechronionych objętościach zamkniętych ciśnienie związane z wybuchem wzrasta zgodnie z krzywą (ryc. 2 - ciśnienie niestłumione). Ciśnienie przy typowym wybuchu mieszaniny py- 
ample, an average silo can withstand overpressure of up to 0.4 bar. One should also bear in mind that the explosion pressure is characterised by rapid growth. If the suppression system is activated at an appropriate time, the pressure increase will be interrupted to assume the expected shape according to the curve - suppressed explosion (fig. 2). The lower value of pressure is called reduced explosion pressure $P_{\text {red }}$

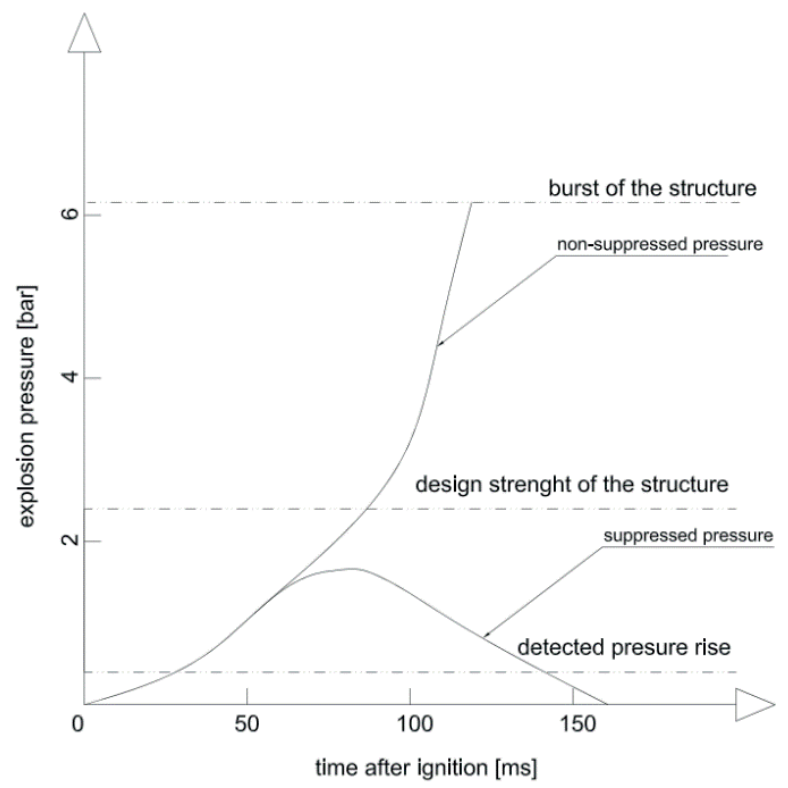

łowo-powietrznej może sięgać do 10 bar. Ciśnienie o tej wartości jest zbyt duże dla większości urządzeń procesowych o typowej konstrukcji. Przykładowo przeciętny silos wytrzymuje nadciśnienie maksimum 0,4 bar. Należy także mieć na uwadze, że ciśnienie wybuchu charakteryzujące się wysoką dynamiką wzrostu. Jeśli system tłumiący zostanie aktywowany w odpowiedniej chwili, to nastąpi zatrzymanie przyrostu ciśnienia, które przewidywalnie ukształtuje się zgodnie z krzywą - stłumiony wybuch (ryc. 2). Niższa wartość ciśnienia nazywana jest zredukowanym ciśnieniem wybuchu $P_{\text {red }}$ (z ang. reduced explosion pressure).

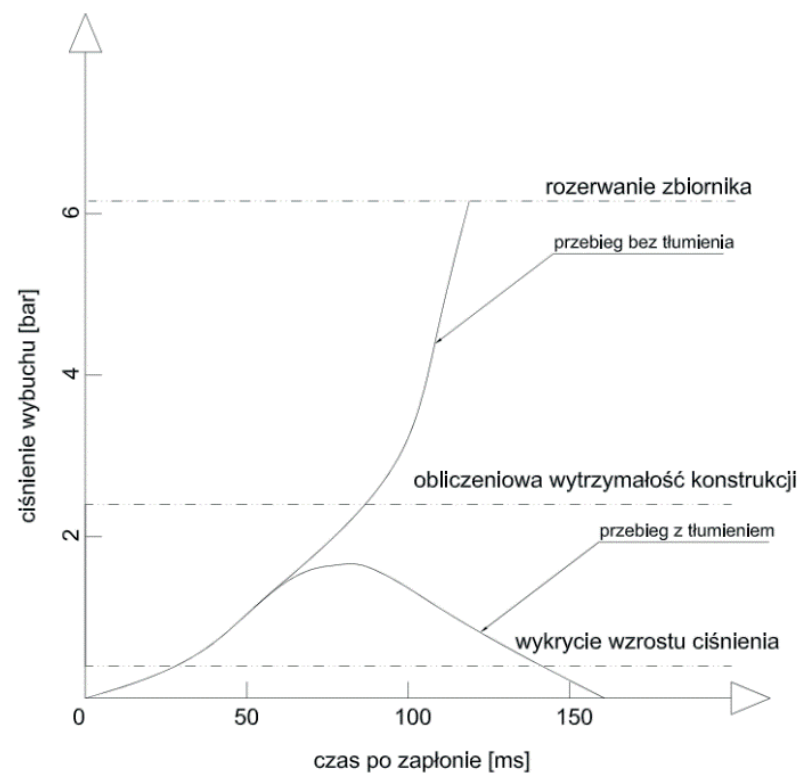

Figure 2. The theoretical course of the explosion in a closed volume as a function of time and pressure (with and without explosion suppression) Rycina 2. Teoretyczny przebieg wybuchu w zamkniętej objętości w funkcji czasu i ciśnienia (z tłumienie i bez tłumienia wybuchu) Source: Prepared on the basis of: Barton J., Dust explosion prevention and protection. A practical guide., published by IChemE, Rugby, $2002, \mathrm{p} .77$. Źródło: Opracowanie na podstawie: Barton J., Dust explosion prevention and protection. A practical guide., wyd. IChemE, Rugby, 2002 , str. 77.

For a dust-air explosion within a closed volume, the value of reduced pressure $P_{\text {red }}$ is conditional on the following factors:

- the type of explosion detectors used, their location inside the protected process equipment and the detection method employed (electromagnetic radiation, exceeding the threshold pressure value, pressure increase value),

- fire-extinguishing agent performance,

- the number and distribution of HRD equipment and the resultant concentration of the suppressant,

- the geometry of the protected volume.

The pressure generated at an early stage of the explosion (dust explosions are mostly deflagrations) in an enclosed space is propagating in the medium faster than the flame front. Blast wave velocity is similar to the speed of sound propagation in the medium. The basic device used to detect the explosion is the sensor mounted inside the protected device. The sensors used
Dla wybuchu pyłowo-powietrznego w zamkniętej objętości, wielkość ciśnienia zredukowanego $P_{\text {red }}$ można uzależnić od niżej wymienionych czynników:

- typu detektorów wykrywających wybuch, ich położenia wewnątrz chronionego aparatu procesowego oraz stosowanego sposobu detekcji (promieniowanie elektromagnetyczne, przekroczenie wartości ciśnienia progowego, wartość przyrostu ciśnienia),

- skuteczności środka gaśniczego,

- liczby i rozmieszczenia gaśnic HRD, a co za tym idzie wypadkowej koncentracji medium tłumiącego,

- geometrii chronionej kubatury.

Ciśnienie wytworzone we wczesnej fazie wybuchu (wybuchowy pyłowe w większości są typu deflagracyjnego) w zamkniętej przestrzeni rozchodzi się w ośrodku szybciej niż front płomienia. Prędkość przemieszczania fali ciśnienia zbliżona 
for detecting explosions are set to identify exceeded pressure thresholds inside the protected space, pressure increase speeds greater than the predefined value, and flaming combustion. The detection points must take into account both the operation of the sensor under conditions typical of the system, and the unfavourable variants of process conditions, including increased temperatures, humidity or pressure connected with a given industrial process. The threshold values in sensors performing the detection function may be set to a specific value. This allows the use of detectors in an appropriate configuration for specific processes and phenomena which may generate interference.

Membrane sensors are the most common in the HRD systems used. The deformation of the sensor membrane generates a signal in the form of voltage, the value of which is proportional to the force causing the deformation. In practice, this facilitates the sensitivity configuration of the explosion suppression system. There are three types of sensors: single-membrane - typically used for measuring pressure values; with two smaller membranes designed to measure the rate of pressure increase; and combined sensors containing both the pressure membrane/ membranes and an infrared sensor, which detects the occurrence of the flame (optical probe). Such a probe detects electromagnetic radiation in the infrared range (which corresponds to the frequencies emitted during combustion).

HRD containers are usually mounted outside the protected areas (on their external surfaces), while the nozzles spreading the extinguishing agent are inserted into the interior of the protected device. The containers differ by manufacturer in shape and size. In practice, containers with volumes from 3 to $60 \mathrm{dm}^{3}$ and external diameters from 20 to $130 \mathrm{~mm}$ are the most common. Manufacturers use various designs of containers, spreader nozzles, and extinguishing media. Some containers are filled with extinguishing media under a pressure of 50 to $60 \mathrm{bar}$. Increasing the pressure causes the tank's lid to open and the extinguishing material is forced into the protected space. There are a variety of methods of closing a tank with the extinguishing medium. Some include advanced structures, which, instead of a torn-off membrane feature ultra-fast solenoid valves. Such valves can react and begin releasing the extinguishing mixture in a matter of milliseconds. Below (fig. 3 ) is a cross-section of a HRD demonstrator container produced in a project implemented by CNBOP-PIB and financed by NCRD entitled "Innovative explosion protection technologies including for highly protected facilities". jest do prędkości rozchodzenia się dźwięku w danym ośrodku. Podstawowym urządzeniem, którego zadaniem jest wykrycie wybuchu, jest czujnik zamontowany wewnątrz chronionego aparatu. Czujniki stosowane do detekcji wybuchu działają w oparciu o przekroczenie zakładanego progu ciśnienia wybuchu wewnątrz chronionej przestrzeni, bądź gdy prędkość narastania ciśnienia przekroczy zadaną wartość lub też zostanie wykryte spalanie płomieniowe. Punkty detekcji muszą uwzględniać zarówno pracę czujnika w typowych dla instalacji warunkach, jak i niekorzystny wariant warunków procesowych np. podwyższoną temperaturę, wilgotność czy zwiększone ciśnienie związane z danym procesem przemysłowym. Wartości progowe w sensorach pełniących funkcję detekcji można ustawić na zadany poziom. Pozwala to na zastosowanie detektorów w odpowiedniej konfiguracji, dla konkretnego procesu i zjawisk, które mogą wywołać zakłócenia.

Najczęściej w stosowanych systemach HRD spotykane są czujniki membranowe. Wskutek odkształcenia membrany czujnika generowany jest sygnał w postaci napięcia, którego wartość jest proporcjonalna do siły wywołującej odkształcenie. W praktyce pozwala to na wygodną konfigurację czułości systemu tłumienia wybuchów. Spotykane są trzy typy czujników: z pojedynczą membraną - służące zazwyczaj do pomiarów wartości ciśnienia - z dwiema mniejszymi membranami, których zadaniem jest zazwyczaj pomiar szybkości narastania ciśnienia oraz czujniki łączone zawierające zarówno membranę/membrany ciśnieniowe, jak i czujnik podczerwony IR - który rejestruje wystąpienie płomienia (sonda optyczna). Sonda taka rejestruje promieniowanie elektromagnetyczne w paśmie podczerwieni (co odpowiada częstotliwościom emitowanym podczas spalania).

Butle HRD montuje się zazwyczaj na zewnątrz przestrzeni chronionych (na ich zewnętrznych powierzchniach), natomiast dysze rozpraszające środek gaśniczy wyprowadzone są do środka chronionego urządzenia. W zależności od producenta butle mają różne rozmiary i kształty. W praktyce najczęściej stosowane są jednak butle o pojemnościach od 3 do $60 \mathrm{dm}^{3}$ i średnicach zewnętrznych od 20 do $130 \mathrm{~mm}$. Producenci stosują różnorakie konstrukcje butli, rozpraszaczy i mediów gaśniczych. Niektóre butle nabijane są medium gaszącym pod ciśnieniem, wynoszącym zazwyczaj od 50 do 60 bar. Wzrost ciśnienia powoduje otwarcie przesłony zamykającej zbiornik i wtłoczenie materiału gaszącego do chronionej przestrzeni. Sposoby zamknięcia zbiornika z medium gaśniczym są różnorodne. Na przykład zaawansowane konstrukcje zamiast zrywalnej membrany wyposażone są w ultraszybkie elektrozawory. Zawory takie są w stanie zareagować i zacząć uwalniać mieszankę gaszącą w przeciągu kilku milisekund. Poniżej (ryc. 3) przedstawiono przekrój demonstratora butli HRD wytworzonego w projekcie zrealizowanym przez CNBOP-PIB i finansowanym przez NCBR pn. „Innowacyjne technologie zabezpieczeń przed wybuchem w tym obiektów szczególnie chronionych". 


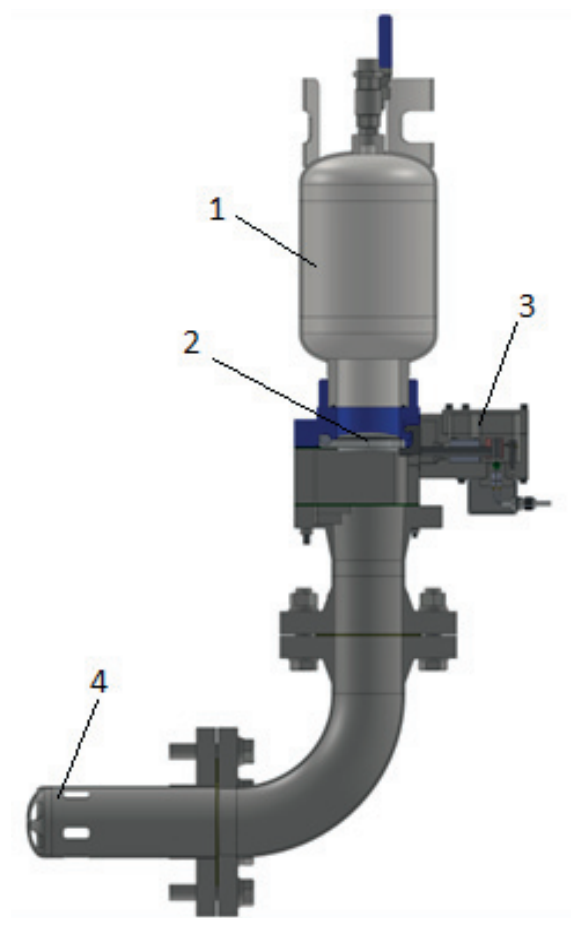

Figure 3. Structure of an HRD extinguisher: (1) tank, (2) valve, (3) opening section, (4) spray nozzle Rycina 3. Budowa butli HRD: (1) zbiornik, (2) zawór, (3) sekcja otwierająca, (4) dysza rozpylająca

Source: Own elaboration

Źródło: Opracowanie własne.

Both the valve and the coupling of the container and the nozzle have such internal diameters that reduce the resistance of discharging the extinguishing agent, while retaining the utility of the device. The time for the valve to open and the discharge rate are the critical factors which determine the effectiveness of explosion suppression. The value characterising the amount of discharged suppression agent in time is defined as $\mathrm{dm} / \mathrm{dt}$. This value is directly proportional to the area of the cross-section through which the extinguishing medium flows - marked as $A-$ and the product of the root of extinguishing medium pressure $P_{N 2}$. This relation can be expressed as:

$$
\frac{d m}{d t} \approx A \sqrt{P_{N 2}}
$$

It follows from the relation above that the size of the crosssection of the discharging area $A$ is more significant than the storage/injection pressure of the extinguishing medium.

When the suppression system is activated, the extinguishing medium stored in the container moves under pressure towards the spreader nozzle and then into the protected closed space. In some cases, another membrane is installed between the nozzle (and container) and the protected volume. It is torn during the release of pressure from the container, which also causes the extension of the telescopic nozzle to a specific depth of the protected device. This solution protects the nozzles from clogging during normal device operation and does not interfere with the flow during the production process. The structure of the nozzle depends on the type of suppressant. Fire-extinguishing powders often require special nozzle geometry, as the aim is to spread
Zarówno zawór, jak i łączenie butli z dyszą posiadają tak dobraną średnicę wewnętrzną, aby wyładowanie środka gaśniczego przebiegało z jak najmniejszymi oporami przy jednoczesnym zachowaniu przez urządzenie jego funkcjonalności użytkowej. Czas otwarcia zaworu i szybkość rozładowania butli są czynnikami krytycznymi - to one decydują o skutecznym stłumieniu wybuchu. Wielkość charakteryzująca ilość rozładowanej masy tłumiącej w czasie oznaczana jest jako $d m / d t$. Wartość ta jest wprost proporcjonalna do powierzchni przekroju poprzecznego, przez który przepływa środek gaśniczy - oznaczanej jako $A$ - i iloczynu pierwiastka ciśnienia przechowywania masy gaszącej $P_{N 2}$. Zależność tę można zapisać, jako:

$$
\frac{d m}{d t} \approx A \sqrt{P_{N 2}}
$$

Powyższa zależność stanowi o tym, że wielkość przekroju powierzchni wyładowania $A$ ma większe znaczenie niż ciśnienie przechowywania/wtrysku środka gaśniczego.

Przechowywany w butli środek gaśniczy w przypadku uruchomienia systemu tłumiącego przemieszcza się pod ciśnieniem do dyszy rozpraszającej - a następnie do chronionej przestrzeni zamkniętej. Niekiedy dyszę (i butlę) od chronionej objętości oddziela kolejna membrana, która zrywana jest podczas uwalniania ciśnienia z butli, co jednocześnie powoduje wysunięcie teleskopowej dyszy na określoną głębokość chronionego urządzenia. Rozwiązanie takie zabezpiecza dysze przed zatkaniem podczas normalnej pracy chronionego urządzenia i nie zaburza przepływu podczas procesu produkcyjnego. Budowa dyszy zależna jest oczywiście od stosowanego typu środka tłumiącego. W przy- 
the agent in the protected volume in a fast and even manner. The main requirements set for HRD systems can be reduced to three general points:

- a high discharge factor of the suppressing mass,

- a highly dynamic discharged material

- sufficient spreading angle of the suppressant.

It is logical that both the discharge factor and the high rate of discharge are connected with the flow diameter of the extinguishing mass and the pressure forcing the agent out of the nozzle. These values also depend on the bends and curves between the flow-through elements. The spread angle largely depends on nozzle structure and geometry and the speed at which the extinguishing medium moves. A well-designed system becomes empty after less than $100 \mathrm{~ms}$, while the first dose of the extinguishing material reaches the endangered area after just $10 \mathrm{~ms}$ from the moment of discovering the threat. The container can discharge the extinguishing agent due to the storage pressure (surge) and movement speed to a distance of 6-8 $\mathrm{m}$.

A spherical acid-resistant steel tank with a volume of $1 \mathrm{~m}^{3}$ was produced for the purposes of research in the abovementioned project. A cover equipped with a fixing mechanism with a slewing ring propelled by a pneumatic actuator was used for closing the tank. A set of dispersion systems was installed in the tank to generate an explosive atmosphere - a mixture of dust and air. The system injecting dust into the sphere and the dust and air mixing system were produced in accordance with the PN-EN14034 standards. The tank has security measures guaranteeing an appropriate level of work safety, e.g. a lid closure sensor, an actuator lock, a system preventing the opening of the lid on the sphere in the case of excess pressure inside (fig. 4). The HRD extinguishers used can be installed at $90^{\circ}$ on the DN75 flange connection visible in figure 5 .

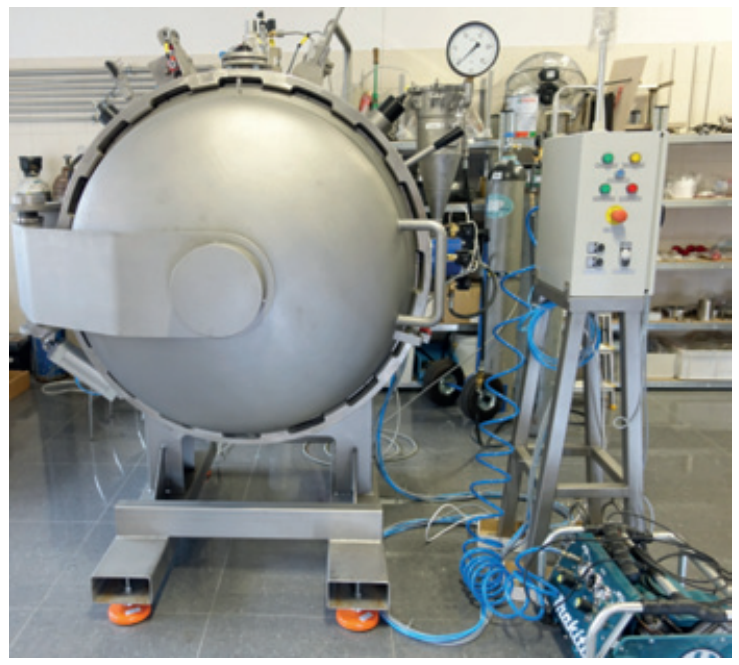

Figure 4. Test stand

Rycina 4. Stanowisko badawcze

Source: Own elaboration.

Źródło: Opracowanie własne. padku proszków gaśniczych częstokroć wymaga się specjalnej geometrii dyszy, która ma na celu szybkie i równomierne rozproszenie medium w objętości chronionej. Główne wymogi stawiane systemom HRD można ograniczyć do trzech ogólnych punktów:

- wysoki współczynnik wyładowania masy tłumiącej,

- wysoka dynamika wyładowanego materiału,

- dostateczne kątowe rozproszenie środka tłumiącego.

Logiczne jest, że zarówno współczynnik wyładowania, jak i wysoka prędkość wyładowania ściśle związane są ze średnicą przepływu masy gaszącej i ciśnieniem miotającym ładunkiem. Wielkości te zależne są również od zagięć czy zakrętów pomiędzy elementami przepływowymi. Kątowe rozpraszanie uwarunkowane jest przede wszystkim budową i geometrią dyszy oraz w dużej mierze prędkością przemieszczania się ładunku gaszącego. Dobrze zaprojektowany system opróżnia się całkowicie w czasie krótszym niż 100 ms, zaś pierwsza dawka materiału gaszącego dociera do zagrożonej przestrzeni już po ok. $10 \mathrm{~ms}$ od momentu wykrycia zagrożenia. Butla jest w stanie miotać środkiem gaszącym z racji ciśnienia przechowywania (wyrzutu) i prędkości przemieszczania się ładunku na odległość $6-8 \mathrm{~m}$.

Na potrzeby badań w przywołanym wcześniej projekcie wykonano sferyczny zbiornik ze stali kwasoodpornej o objętości $1 \mathrm{~m}^{3}$. Do jego zamknięcia zastosowano pokrywę wyposażoną w mechanizm bagnetowy z obrotowym pierścieniem napędzanym siłownikiem pneumatycznym. W zbiorniku zainstalowano zestaw układów dyspersyjnych służących do tworzenia atmosfery wybuchowej - mieszaniny pyłu z powietrzem. Układy wtrysku pyłu do kuli oraz system mieszania pyłu i powietrza wykonano zgodnie z wymaganiami serii norm PN-EN14034. Zbiornik posiada zabezpieczenia gwarantujące odpowiedni poziom bezpieczeństwa pracy, m.in.: czujnik domknięcia pokrywy, blokadę siłownika, układ uniemożliwiający otwarcie pokrywy w kuli przy nadciśnieniu w jej wnętrzu (ryc. 4). Zastosowane gaśnice HRD mają możliwość montażu pod kątem $90^{\circ}$ na przyłączu kołnierzowym DN75 widocznym na rycinie 5 .

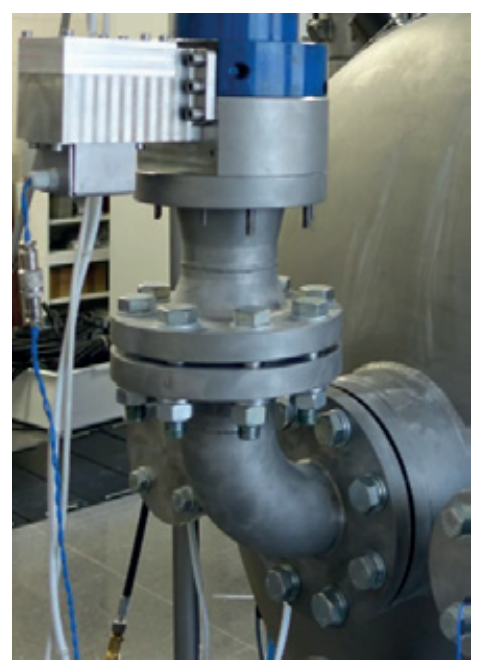

Figure 5. Flange connection DN75

Rycina 5. Przyłącze kołnierzowe DN75

Source: Own elaboration.

Źródło: Opracowanie własne. 
A piezo-electric dynamic pressure sensor coupled with a voltage signal boosting system and data acquisition system was placed inside the tank chamber. This system allows recording explosion pressure changes with time. The ignition of a dust-air cloud is triggered by pyrotechnic igniters. The pressure effect of the ignition source was determined during blank tests, allowing to rule it out by introducing appropriate adjustments in the recording software. Below is a description of issues connected with the use of pyrotechnic igniters in the studied technology demonstrator system. An element which may introduce uncertainty in determining the extinguishing effectiveness of the HRD system in a small tested area was the impact of ignition heads with an ignition energy of $2 \times 5 \mathrm{~kJ}$, which caused a temporary surge in pressure recorded in the chart below (fig. 6).

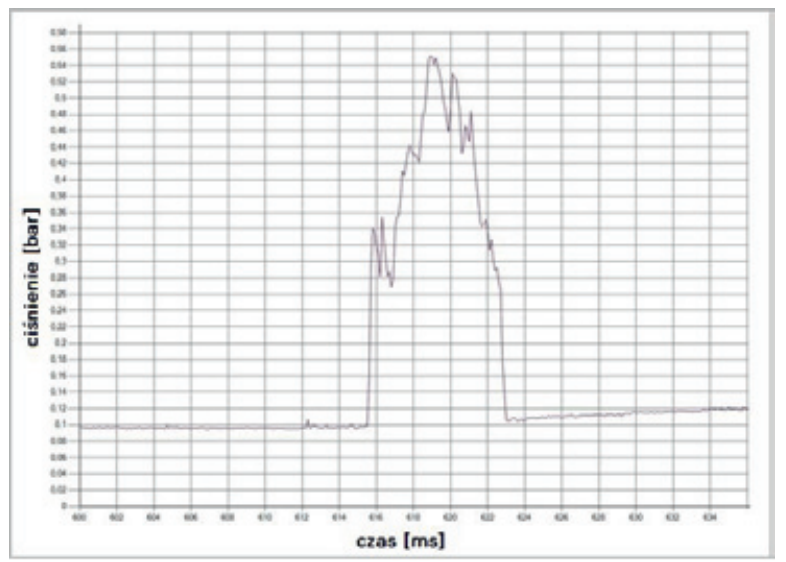

Wewnątrz komory zbiornika umieszczono piezoelektryczny czujnik ciśnienia dynamicznego, który został połączony z układem wzmocnienia sygnału napięciowego oraz systemem akwizycji danych. System ten umożliwia rejestrację zmian ciśnienia wybuchu w czasie. Zapłon obłoku pyłowo-powietrznego realizowany jest przez wybuch zapalników pirotechnicznych. Ciśnieniowy efekt źródła zapłonu został określony w trakcie tzw. ślepych prób, co pozwoliło na jego usunięcie poprzez wprowadzenie odpowiednich poprawek w oprogramowaniu rejestrującym. Poniżej opisano problematykę związaną z zastosowaniem pirotechnicznego źródła zapłonu w badanym układzie demonstratora. Elementem mogącym wprowadzić kryterium niepewności w oznaczeniu skuteczności gaśniczej systemu HRD w małej przestrzeni badawczej był wpływ główek zapalczych o energii zapłonu $2 \times 5 \mathrm{~kJ}$, których zapłon powodował chwilowy skok ciśnienia zarejestrowany na poniższym wykresie (ryc. 6).

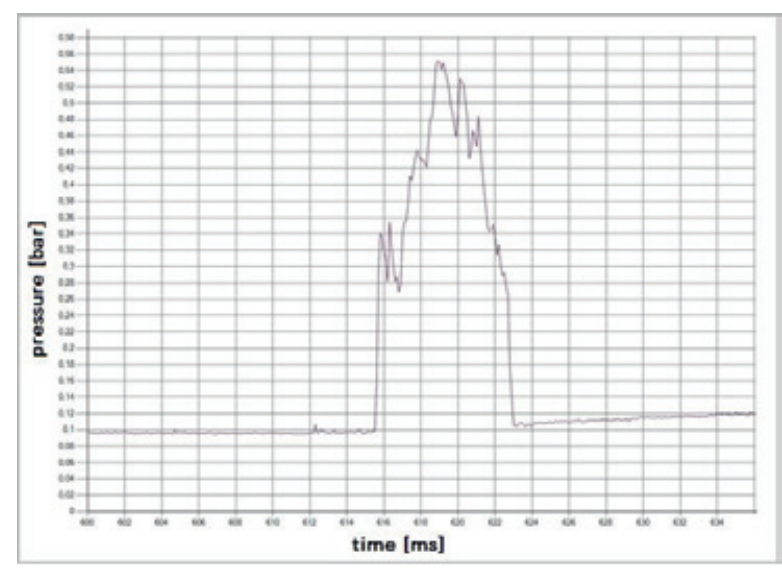

Figure 6. Registered pressure stroke from the $2 \times 5 \mathrm{~kJ}$ ignition heads

Rycina 6. Zarejestrowany skok ciśnienia pochodzący od główek zapalczych $2 \times 5 \mathrm{~kJ}$

Source: Own elaboration.

Źródło: Opracowanie własne.

At an early stage, due to the injection of dust into the tank with a volume of $1 \mathrm{~m}^{3}$ a pressure increase to about 0.12 bar is recorded. This is combined with the effect of ignition of ignition heads, which causes a pressure surge in the tank, which on average reaches values from 0.3 bar to as much as slightly over 0.6 bar. Explosion pressure sensors activate the system when the preset value is exceeded. This value is set in the range of $0.05-0.5$ bar. Therefore, ignition heads alone may set off the HRD extinguishers. To avoid such unfavourable effect that would interfere with the test procedure, the ignition energies of dust-air mixtures were reduced to $5 \mathrm{~kJ}$. The obtained $P_{e x}$ and $(\mathrm{dp} / \mathrm{dt})_{\mathrm{ex}}$ values are similar to the values obtained for the ignition energy of $2 \times 5 \mathrm{~kJ}$. At the same time, the value of activation pressure (launching the injection of the extinguishing powder) at 0.5 bar was retained to rule out the possibility of prematurely activating the extinguishing system.

One of the most important elements of the system is the explosion detection sensor, which was designed for early explo-
W początkowej fazie, na skutek wtrysku pyłu do wnętrza zbiornika o pojemności $1 \mathrm{~m}^{3}$, rejestrowany jest wzrost ciśnienia do około 0,12 bar. Dodatkowo nakłada się na to efekt zapłonu główek zapalczych, który wywołuje skok ciśnienia w zbiorniku, średnio do wartości 0,3 bar, a nawet przekracza nieznacznie 0,6 bar. Czujniki ciśnienia wybuchu aktywują działanie systemu po przekroczeniu ustalonej wartości. Wartość tę ustawia się w zakresie 0,05-0,5 bar. Może zatem dojść do sytuacji, w której same główki zapalcze uruchomią gaśnice HRD. W celu uniknięcia takiego niekorzystnego efektu, który zaburzyłby proces badania, obniżono energię zapłonu mieszanin pyłowo-powietrznych do $5 \mathrm{~kJ}$. Osiągane wartości $P_{\mathrm{ex}}$ $\mathrm{i}(\mathrm{dp} / \mathrm{dt})_{\text {ex }}$ są zbliżone do wartości osiąganych w przypadku stosowania energii zapłonu $2 \times 5 \mathrm{~kJ}$. Jednocześnie pozostawiono wartość ciśnienia aktywacji (uruchomienia wtrysku proszku gaśniczego) na poziomie 0,5 bar w celu wyeliminowania zbyt wczesnego aktywowania systemu gaśniczego.

Jednym z ważniejszych elementów systemu jest czujnik detekcji wybuchu, którego zadaniem jest wczesne wykrycie wybu- 
sion detection inside the test chamber. The detector is composed of two dynamic pressure sensors coupled with a signal analysis system and power supply units. The method of detecting the explosion can be selected. The first method involves programming the activation threshold (activation pressure $P_{a}$ ) to a set range. The second one consists in programming an appropriate pressure increase threshold (activation increment $\left.(d p / d t)_{a}\right)$ which activates the extinguishing system.

Two HRD extinguishers with tank volumes $5 \mathrm{dm}^{3}$ and $20 \mathrm{dm}^{3}$ were produced for the purposes of the research project and tests. After receiving the activating signal, the pistons release the lid of the HRD container and eject the powder stored inside. The container tank is under a constant inert gas pressure. The whole process takes no more than $100 \mathrm{~ms}$. Less than $8 \mathrm{~ms}$ is needed to open the piston. Figure 7 presents a container with a working volume of $5 \mathrm{dm}^{3}$ along with an activator system for the lid and a block with a stop valve. chu w komorze badawczej. Detektor składa się z dwóch czujników ciśnienia dynamicznego, połączonych z układem analizy sygnału i zasilaczami. Istnieje możliwość ustawienia sposobu wykrycia wybuchu. Pierwszy polega na zaprogramowaniu progu aktywacji (ciśnienia aktywacji $P_{a}$ ) w ustalonym zakresie. Drugi polega na zaprogramowaniu odpowiedniego progu przyrostu ciśnienia (przyrost aktywacji $(d p / d t)$ )), przy którym następuje uruchomienie systemu gaśniczego.

$\mathrm{Na}$ potrzeby projektu badawczego i badań wykonano dwie gaśnice HRD o pojemności zbiornika ze środkiem gaśniczym $5 \mathrm{dm}^{3}$ i $20 \mathrm{dm}^{3}$. Po otrzymaniu sygnału aktywującego układ tłoków zwalnia klapę spustową butli HRD i wyrzucany jest zawarty w niej proszek. Zbiornik butli jest pod stałym ciśnieniem gazu inertnego. Cały proces trwa nie dłużej niż $100 \mathrm{~ms}$. Otwarcie tłoka przebiega w czasie poniżej $8 \mathrm{~ms}$. Rycina. 7 przedstawia butlę o objętości roboczej $5 \mathrm{dm}^{3}$ wraz układem aktywacji klapy spustowej i bloku z zaworem zamykającym.

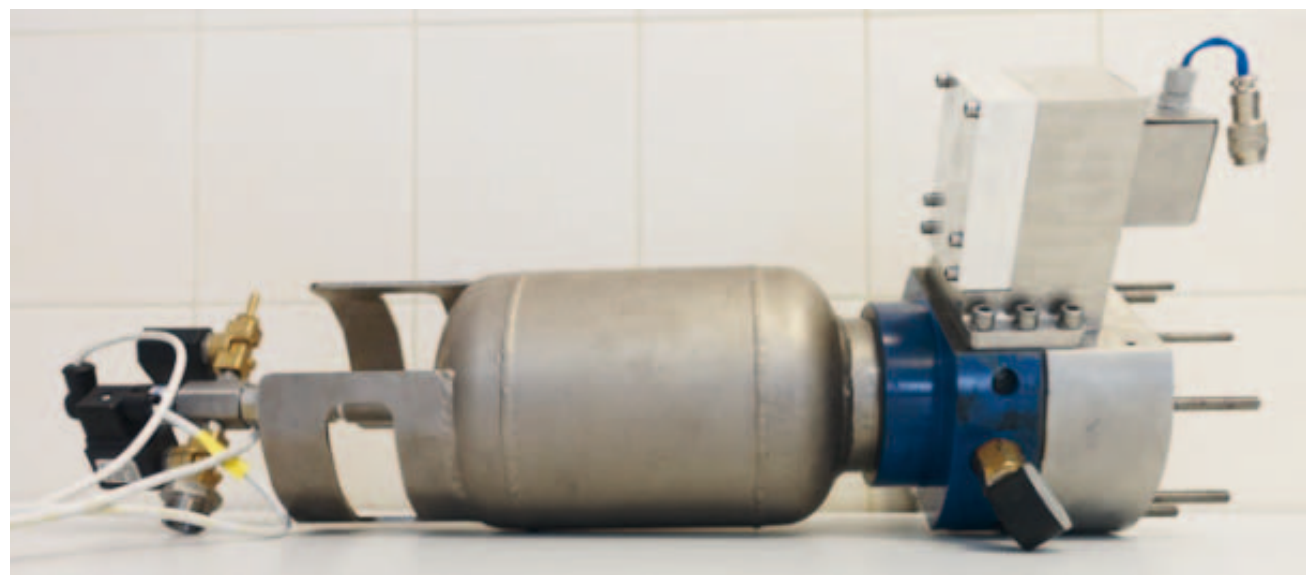

Figure 7. Fragment of HRD fire extinguisher with vol. $5 \mathrm{dm}^{3}$

Rycina 7. Fragment gaśnicy HRD o obj. $5 \mathrm{dm}^{3}$

Source: Own elaboration.

Źródło: Opracowanie własne.

\section{Results}

The study involved a number of tests, including the extinguisher discharge test recorded using a high-speed camera $(1,000$ frames per second). Frame-by-frame photographs of specific tests and applications are shown in figures $8-11$. The first test involved a system without a nozzle. The working pressure inside the extinguisher was determined at 60 bar and the mass of the extinguishing powder was $1 \mathrm{~kg}$. The stages of discharge of the powder and inert gas mixture are shown in figures 8 and 9 . The first sequence of four photographs (fig. 8) presents the following times (from top) $-25 \mathrm{~ms}, 30 \mathrm{~ms}$, $40 \mathrm{~ms}$, and $50 \mathrm{~ms}$. The next sequence (fig. 9) shows $60 \mathrm{~ms}, 70 \mathrm{ms,}$ $80 \mathrm{~ms}, 90 \mathrm{~ms}$, and $100 \mathrm{~ms}$.

It was found that $90 \%$ of the mass of the extinguishing powder is discharged over less than $70 \mathrm{~ms}$. The most intensive ejection of dust occurs at about 30-40 millisecond. After

\section{Wyniki}

W ramach badań przeprowadzono szereg prób, w tym test wyładowania gaśnic -zarejestrowany za pomocą szybkiej kamery (1000 klatek/s). Poklatkowe zdjęcia konkretnych badań i aplikacji przedstawiają ryciny 8-11. W pierwszej kolejności badaniom poddano układ bez zastosowania dyszy. Ciśnienie robocze w gaśnicy ustalono na wartość 60 bar, a masę proszku gaśniczego na 1 kg. Fazy wypływu mieszaniny proszku z gazem inertnym widoczne są na ryc. 8 i 9 . Pierwsza sekwencja czterech zdjęć (ryc. 8) przedstawia kolejno (od góry) czasy - 25 ms, 30 ms, $40 \mathrm{~ms}, 50 \mathrm{~ms}$. Następna sekwencja fotografii (ryc. 9) to czasy $60 \mathrm{~ms}, 70 \mathrm{~ms}, 80 \mathrm{~ms}, 90 \mathrm{~ms}, 100 \mathrm{~ms}$.

Oceniono, że 90\% masy proszku gaśniczego wyładowywane zostaje w czasie poniżej $70 \mathrm{~ms}$. Najbardziej intensywny wyrzut pyłu następuje około 30-40 milisekundy. Po 70 ms widoczna 


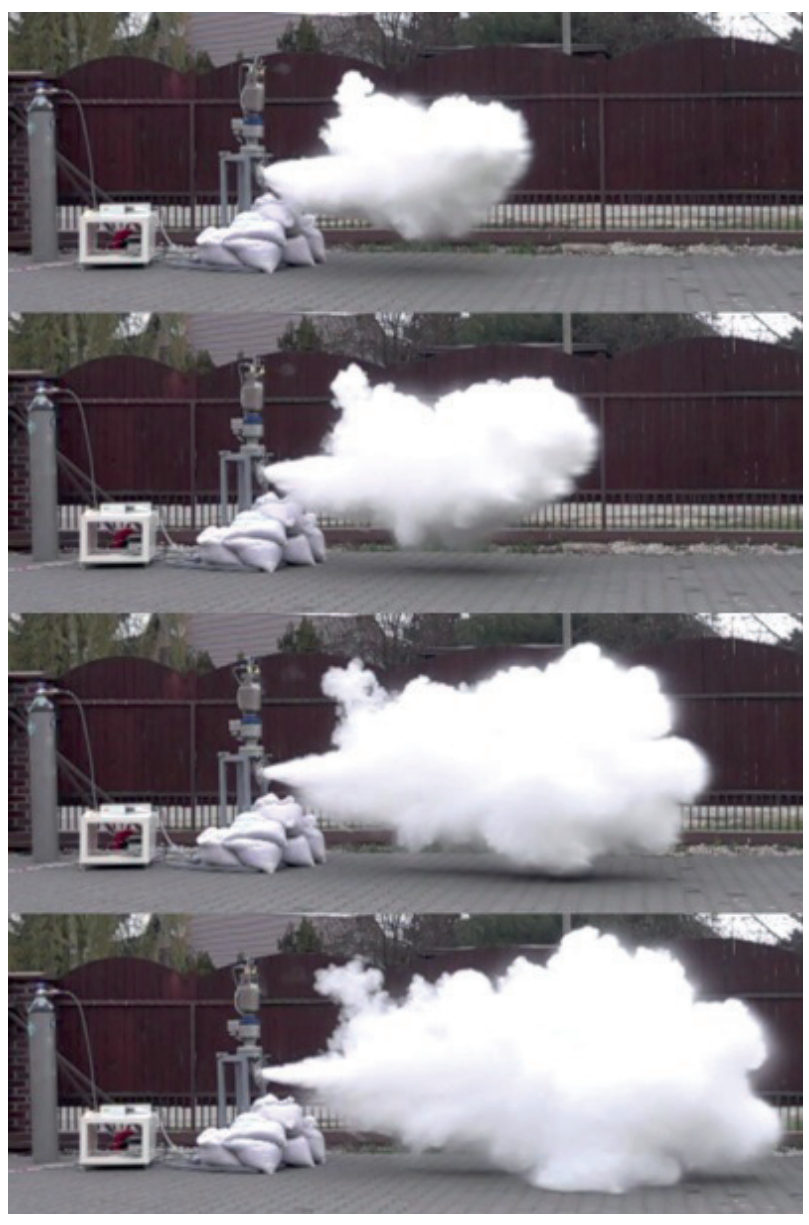

Figure 8. Dispersion of spray powder without nozzle (from above) $25,30,40,50 \mathrm{~ms}$

Rycina 8. Rozproszenie proszku gaśniczego bez dyszy (od góry)

$25,30,40,50 \mathrm{~ms}$

Source: Own elaboration.

Źródło: Opracowanie własne.

$70 \mathrm{~ms}$ the cloud visible in the photograph moves and extends, but the outflow of the powder is insignificant. A small part of the extinguishing powder remains inside the extinguisher and nozzle after the outflow stops.

The second stage involved tests using the nozzle placed at the extinguisher outlet, the purpose of which was to spread the extinguishing powder while retaining the conditions as for the test without the nozzle. Figures 10 and 11 below present the shape of the cloud at specific milliseconds of the test.

It was found that almost all of the mass of the extinguishing powder is discharged over less than $80 \mathrm{~ms}$. After comparing both cases (with and without the nozzle), it should be noted that the use of a spreader nozzle slows down the ejection of the extinguishing powder by about $10 \mathrm{~ms}$. However, if the nozzle is present, the powder stream becomes ring-shaped around the nozzle. Therefore, it may be concluded that using the nozzle leads to a more even distribution of the powder within the protected space. This means that a higher-volume area would be filled with the extinguishing agent, improving the effectiveness of the system.

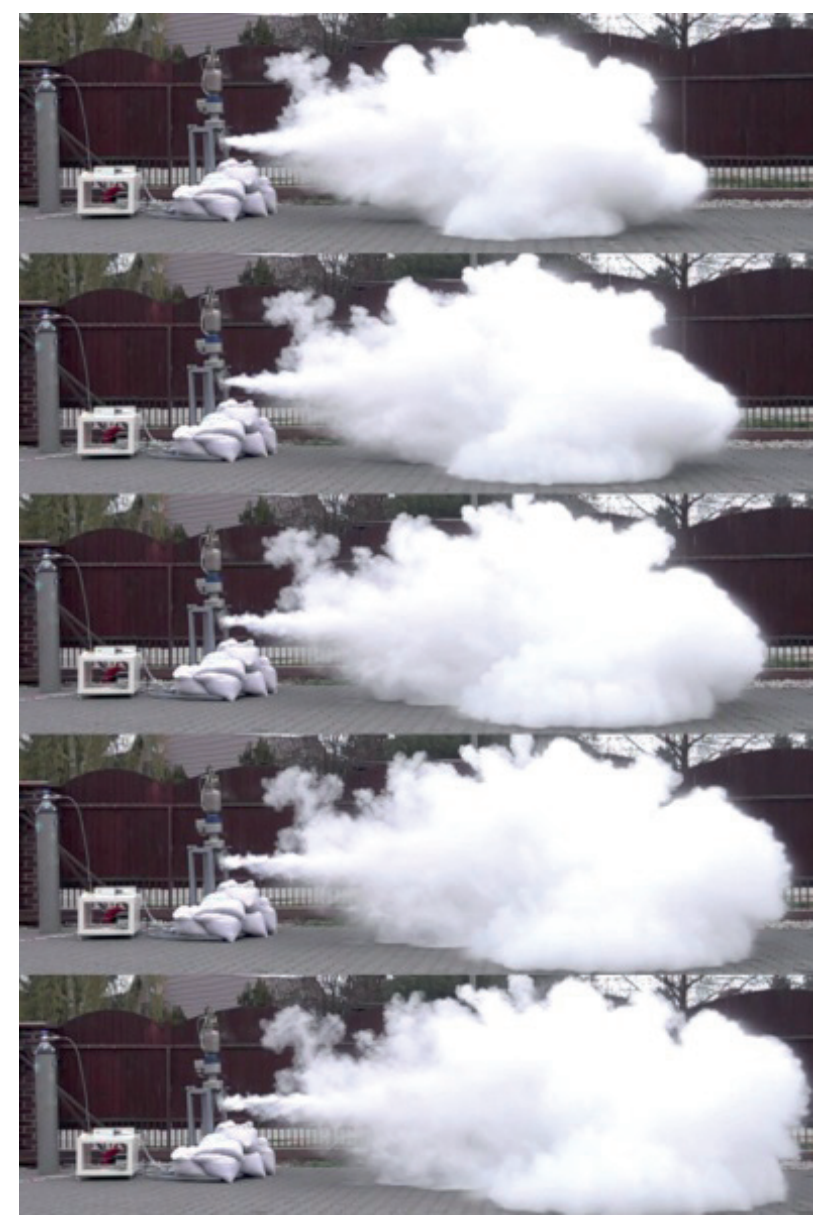

Figure 9. Dispersion of spray powder without nozzle (from above) $60,70,80,90,100 \mathrm{~ms}$

Rycina 9. Rozproszenie proszku gaśniczego bez dyszy (od góry)

$60,70,80,90,100 \mathrm{~ms}$

Source: Own elaboration.

Źródło: Opracowanie własne.

na zdjęciu chmura porusza się i rozszerza, ale wypływ proszku jest nieznaczny. Niewielka część proszku gaśniczego pozostaje w gaśnicy i w dyszy po zakończeniu wypływu.

W drugim etapie wykonano badania z użyciem dyszy umieszczonej na zakończeniu wylotu z gaśnicy, której celem było rozproszenie proszku gaśniczego, przy zachowaniu warunku jak dla próby bez dyszy. Na ryc. 10 i 11 przedstawiono kształt chmury w poszczególnych milisekundach testu.

Zaobserwowano, że praktycznie cała masa proszku gaśniczego wyładowywana jest w czasie krótszym niż 80 ms. Porównując oba przypadki (z dysząi bez niej), należy zauważyć, że zastosowanie dyszy dyspersyjnej spowalnia wyrzut proszku gaśniczego o ok. $10 \mathrm{~ms}$. Jednakże w przypadku obecności dyszy daje się zaobserwować ukierunkowanie strumienia proszku na kształt pierścienia wokół dyszy. Można wobec tego wnioskować, że użycie dyszy pozwala na uzyskanie bardziej równomiernego rozkładu proszku w chronionej przestrzeni. Oznacza to, że w tym przypadku obszar o większej kubaturze zostanie wypełniony środkiem gaśniczym, a tym samym poprawiona zostanie skuteczność systemu. 


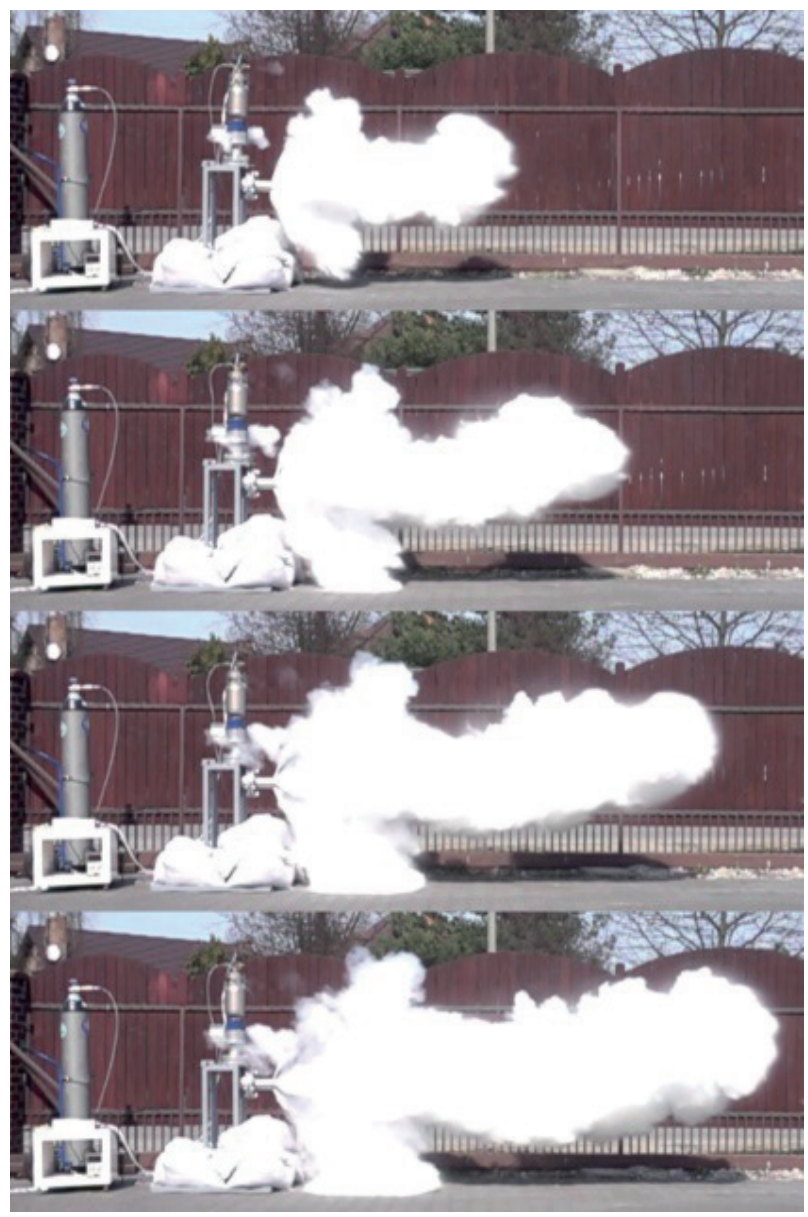

Figure 10. Dispersion of spray powder with nozzle (from above) $25,30,40,50 \mathrm{~ms}$

Rycina 10. Rozproszenie proszku gaśniczego z dyszą (od góry)

$25,30,40,50 \mathrm{~ms}$

Source: Own elaboration.

Źródło: Opracowanie własne.

Tests of the HRD system using a container with a volume of $1 \mathrm{~m}^{3}$ involved the following activities:

1. Causing the explosion of the dust-air mixture with known $P_{\text {max }}$ and $(\mathrm{dp} / \mathrm{dt})_{\max }$ values;

2. Recording the explosion pressure during the operation of the active suppression system.

3. An analysis of the effectiveness of explosion suppression system operation on the basis of a comparison of pressure changes $p(t)$ for the suppressed and non-suppressed explosions.

4. A graphical representation of the pressure changes $p(t)$ for the non-suppressed and suppressed explosions in a single chart.

Before starting to assess the effectiveness of the HRD system, the explosive parameters of two types of dust - lycopodium and potato starch - were determined. The following results were obtained:

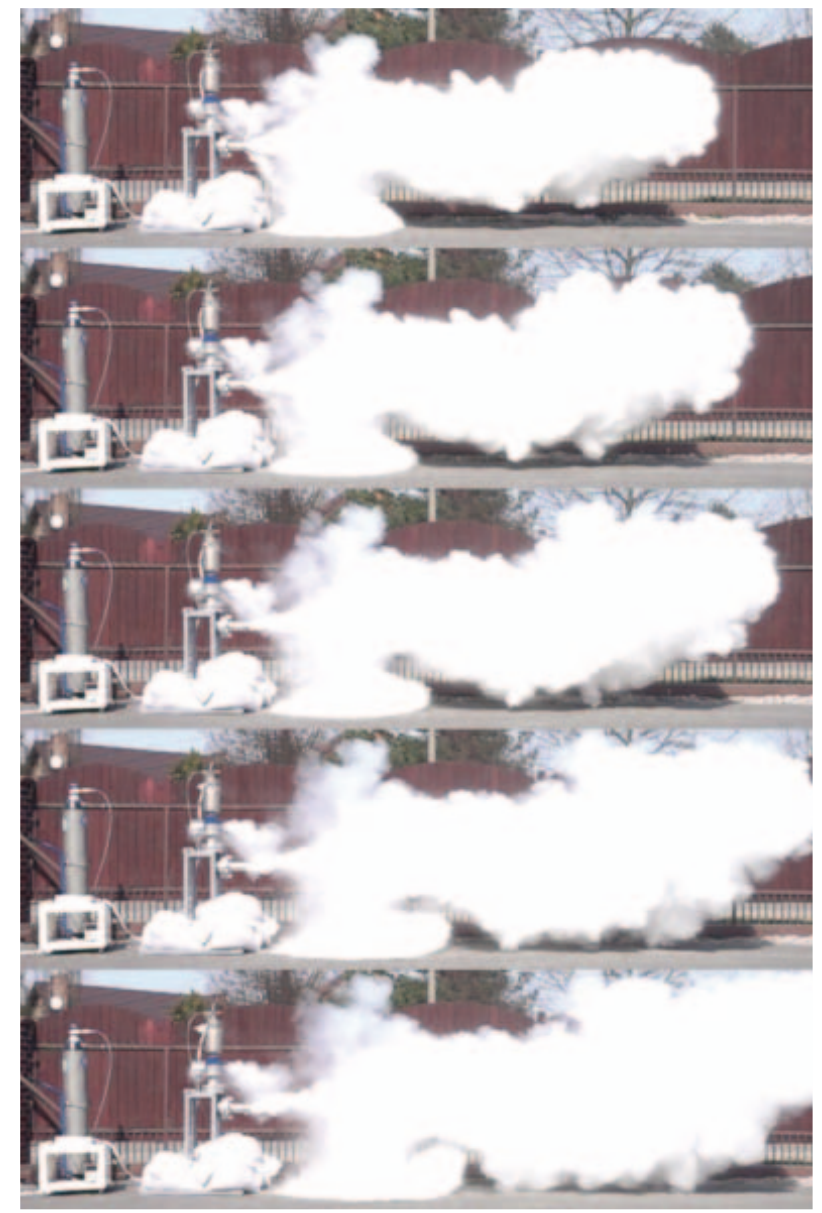

Figure 11. Dispersion of spray powder with nozzle (from above) $60,70,80,90,100 \mathrm{~ms}$

Rycina 11. Rozproszenie proszku gaśniczego z dyszą (od góry)

$60,70,80,90,100 \mathrm{~ms}$

Source: Own elaboration.

Źródło: Opracowanie własne.

Badania systemu HRD z wykorzystaniem zbiornika o objętości $1 \mathrm{~m}^{3}$ zakładały przeprowadzenie następujących działań:

1. Doprowadzenie do wybuchu mieszaniny pyłu i powietrza o znanych wartościach $\mathrm{P}_{\max } \mathrm{i}(\mathrm{dp} / \mathrm{dt})_{\max }$;

2. Rejestracja ciśnienia wybuchu w trakcie działania aktywnego systemu tłumienia;

3. Analiza skuteczności działania aktywnego systemu tłumienia wybuchu na podstawie porównania przebiegów ciśnienia $\mathrm{p}(\mathrm{t})$ dla wybuchu nietłumionego i tłumionego;

4. Graficzna prezentacja przebiegów ciśnienia p(t) dla wybuchu nietłumionego i tłumionego na jednym wykresie.

Przed przystąpieniem do oceny skuteczności systemu HRD wyznaczono parametry wybuchowości dla dwóch pyłów: likopodium i skrobi ziemniaczanej. Uzyskano następujące wyniki:

$P_{\text {ex }}=8,3[\mathrm{bar}] \mathrm{i}(\mathrm{dp} / \mathrm{dt})_{\mathrm{ex}}=211,6[\mathrm{bar} / \mathrm{s}]-$ likopodium $-250\left[\mathrm{~g} / \mathrm{m}^{3}\right]$,

$P_{e x}=7,74[\mathrm{bar}] \mathrm{i}(\mathrm{dp} / \mathrm{dt})_{\mathrm{ex}}=196,67[\mathrm{bar} / \mathrm{s}]-$ likopodium $-500\left[\mathrm{~g} / \mathrm{m}^{3}\right]$, 


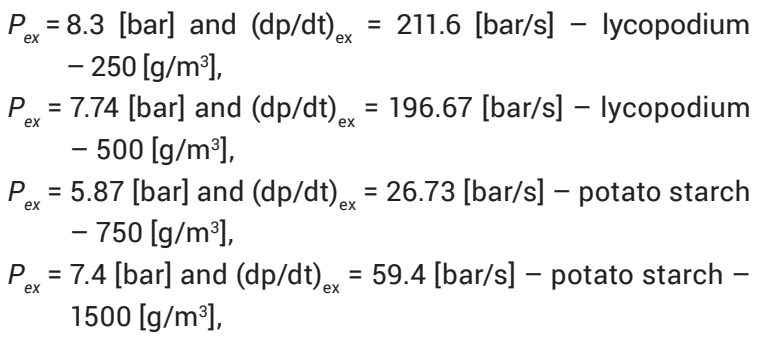

Each test was performed using the following conditions:

- extinguishing powder mass in the container $-1 \mathrm{~kg}$,

- inert gas fill pressure -60 bar,

- ignition delay time $-600 \mathrm{~ms}$,

- explosion pressure activating the HRD system - 0.5 bar',

- ignition with an energy of $5 \mathrm{~kJ}$.

Test No. 1. Suppression of the explosion of lycopodium dust at a concentration of $250 \mathrm{~g} / \mathrm{m}^{3}$

The test was repeated three times for a given dust concentration. A lycopodium and air mixture at a dust concentration of $250 \mathrm{~g} / \mathrm{m}^{3}$ was tested. Such parameters allowed a decrease in pressure from $P_{e x}=8.3$ bar to $P_{\text {red }}=7.65$ bar. After exceeding the activation pressure of 0.5 bar (after $t \sim 670 \mathrm{~ms}$ ), the HRD extinguisher was activated. The extinguishing powder was discharged into the $1 \mathrm{~m}^{3}$ volume of the tank. Over the next $30-40 \mathrm{~ms}$ a considerable part of the powder was ejected into the tank, forming a mixture suppressing the explosion. In this stage the dust explosion was progressing very fast. After $30-40 \mathrm{~ms}$ the temporary pressure value of 4-4.5 bar and the maximum pressure increase rate $(d p / d t)$ ( 210 bar/s) were reached. The explosion developed very quickly. Due to the relatively low volume of the tank, it is not possible - with the current configuration - to apply the extinguishing powder sufficiently early to achieve a stronger extinguishing effect. In the chart (fig. 12) the reduced pressure (red line) reaches a high value, close to the maximum explosion pressure (blue line).

Test No. 2. Suppression of the explosion of lycopodium dust at a concentration of $500 \mathrm{~g} / \mathrm{m}^{3}$

The test was repeated three times for a given dust concentration. A lycopodium and air mixture at a dust concentration of $500 \mathrm{~g} / \mathrm{m}^{3}$ was tested. Such parameters allowed a decrease in pressure from $P_{e x}=7.74$ bar to $P_{\text {red }}=6.77$ bar. After exceeding the activation pressure of 0.5 bar (after $\mathrm{t} \sim 40 \mathrm{~ms}$ ), the HRD extinguisher was activated. The extinguishing powder was discharged into the $1 \mathrm{~m}^{3}$ volume of the tank. Over the next $30-40 \mathrm{~ms}$ a considerable part of the powder was ejected into the tank, forming a mixture suppressing the explosion. In this stage the dust explosion was progressing very fast. After $30-40 \mathrm{~ms}$ the temporary pressure value of 4-4.5 bar and the maximum pressure increase rate $(d p / d t)(\sim 200 \mathrm{bar} / \mathrm{s})$ were reached. As in the case of the concentration of $250 \mathrm{~g} / \mathrm{m}^{3}$, the explosion developed very quickly. Due to the relatively low volume of the container and system activation pressure at $0.5 \mathrm{bar}$, it is not possible to apply

In an industrial setting activation pressure may be set to $0.1-0.2 \mathrm{bar}$. The sphere with a volume of $1 \mathrm{~m}^{3}$ necessitated a specific method of conducting work and adopting research assumptions.

$$
\begin{aligned}
P_{e x}= & 5,87[\mathrm{bar}] \mathrm{i}(\mathrm{dp} / \mathrm{dt})_{\mathrm{ex}}=26,73[\mathrm{bar} / \mathrm{s}]-\text { skrobia ziemniaczana } \\
& -750\left[\mathrm{~g} / \mathrm{m}^{3}\right], \\
P_{e x}= & 7,4[\mathrm{bar}] \mathrm{i}(\mathrm{dp} / \mathrm{dt})_{\mathrm{ex}}=59,4[\mathrm{bar} / \mathrm{s}]-\text { skrobia ziemniaczana } \\
& -1500\left[\mathrm{~g} / \mathrm{m}^{3}\right] .
\end{aligned}
$$

Testy prowadzono każdorazowo przy zastosowaniu niżej wymienionych warunków:

- masa proszku gaśniczego w butli - $1 \mathrm{~kg}$,

- ciśnienie napełnienia gazem inertnym - 60 bar,

- czas opóźnienia zapłonu - $600 \mathrm{~ms}$,

- ciśnienie wybuchu aktywujące system HRD - 0,5 bar',

- zapłon o energii $5 \mathrm{~kJ}$.

Test $\mathrm{nr}$ 1. Tłumienie wybuchu pyłu likopodium w stężeniu $250 \mathrm{~g} / \mathrm{m}^{3}$ Test powtórzono trzy krotnie dla danego stężenia pyłu. Badaniu poddano mieszaninę likopodium z powietrzem - stężenie pyłu $250 \mathrm{~g} / \mathrm{m}^{3}$. Takie parametry zapewniły zredukowanie ciśnienia z $P_{e x}=8,3$ bar do $P_{\text {red }}=7,65$ bar. Po przekroczeniu ciśnienia aktywacji 0,5 bar (po czasie $t \sim 670 \mathrm{~ms}$ ) uruchomiona została gaśnica HRD. Nastąpiło wyładowanie proszku gaśniczego do przestrzeni zbiornika $1 \mathrm{~m}^{3}$. W ciągu kolejnych 30-40 ms duża część proszku została wprowadzona do zbiornika i utworzyła mieszaninę gaszącą wybuch. W tej fazie wybuch pyłu rozwijał się bardzo szybko. Po 30-40 ms osiągnięto chwilową wartość ciśnienia 4-4,5 bar, a prędkość wzrostu ciśnienia ( $d p / d t)$ wartość maksymalną ( 210 bar/s). Wybuch rozwinął się bardzo szybko. Z uwagi na stosunkowo niewielką objętość zbiornika brak jest możliwości - przy zastosowanej konfiguracji - na podanie proszku gaśniczego odpowiednio wcześnie, aby efekt gaszenia był silniejszy. Na wykresie (ryc. 12) ciśnienie zredukowane (linia koloru czerwonego) osiąga znaczną wartość, bliską maksymalnemu ciśnieniu wybuchu (linia koloru niebieskiego).

Test nr 2. Tłumienie wybuchu pyłu likopodium w stężeniu $500 \mathrm{~g} / \mathrm{m}^{3}$

Test powtórzono trzykrotnie dla danego stężenia pyłu. Badaniu poddano mieszaninę likopodium z powietrzem - stężenie pyłu $500 \mathrm{~g} / \mathrm{m}^{3}$. Takie parametry zapewniły zredukowanie ciśnienia z $P_{e x}=7,74$ bar do $P_{r e d}=6,77$ bar. Po przekroczeniu ciśnienia aktywacji 0,5 bar (po czasie t $~ 640 \mathrm{~ms}$ ) uruchomiona została gaśnica HRD. Nastąpiło wyładowanie proszku gaśniczego do przestrzeni zbiornika $1 \mathrm{~m}^{3}$. W ciągu kolejnych 30-40 ms duża część proszku została wprowadzona do zbiornika i utworzyła mieszaninę gaszącą wybuch. W tej fazie wybuch pyłu rozwijał się bardzo szybko. Po 30-40 ms osiągnął chwilową wartość ciśnienia 4-4,5 bar, a prędkość wzrostu ciśnienia $(d p / d t)$ osiągnęła wartość maksymalną ( 200 bar/s). Podobnie jak w przypadku koncentracji $250 \mathrm{~g} / \mathrm{m}^{3}$ wybuch rozwijał się bardzo szybko. Z uwagi na stosunkowo niewielką objętość zbiornika oraz ciśnienie aktywacji systemu ustalone na 0,5 bar, nie pozwala to na podanie proszku gaśniczego odpowiednio

W warunkach przemysłowych ciśnienie aktywacji można ustawić na wartość 0,1-0,2 bar. Sfera o objętości $1 \mathrm{~m} 3$ narzuciła określony sposób prowadzenia prac oraz przyjętych założeń do badań. 
the extinguishing powder sufficiently early to achieve a stronger extinguishing effect. In the chart (fig. 13) the reduced pressure (red line) has a high value, close to the maximum explosion pressure (blue line). wcześnie, aby efekt gaszenia był silniejszy. Na wykresie (ryc. 13) ciśnienie zredukowane (linia koloru czerwonego) ma dużą wartość, bliską maksymalnemu ciśnieniu wybuchu (linia koloru niebieskiego).

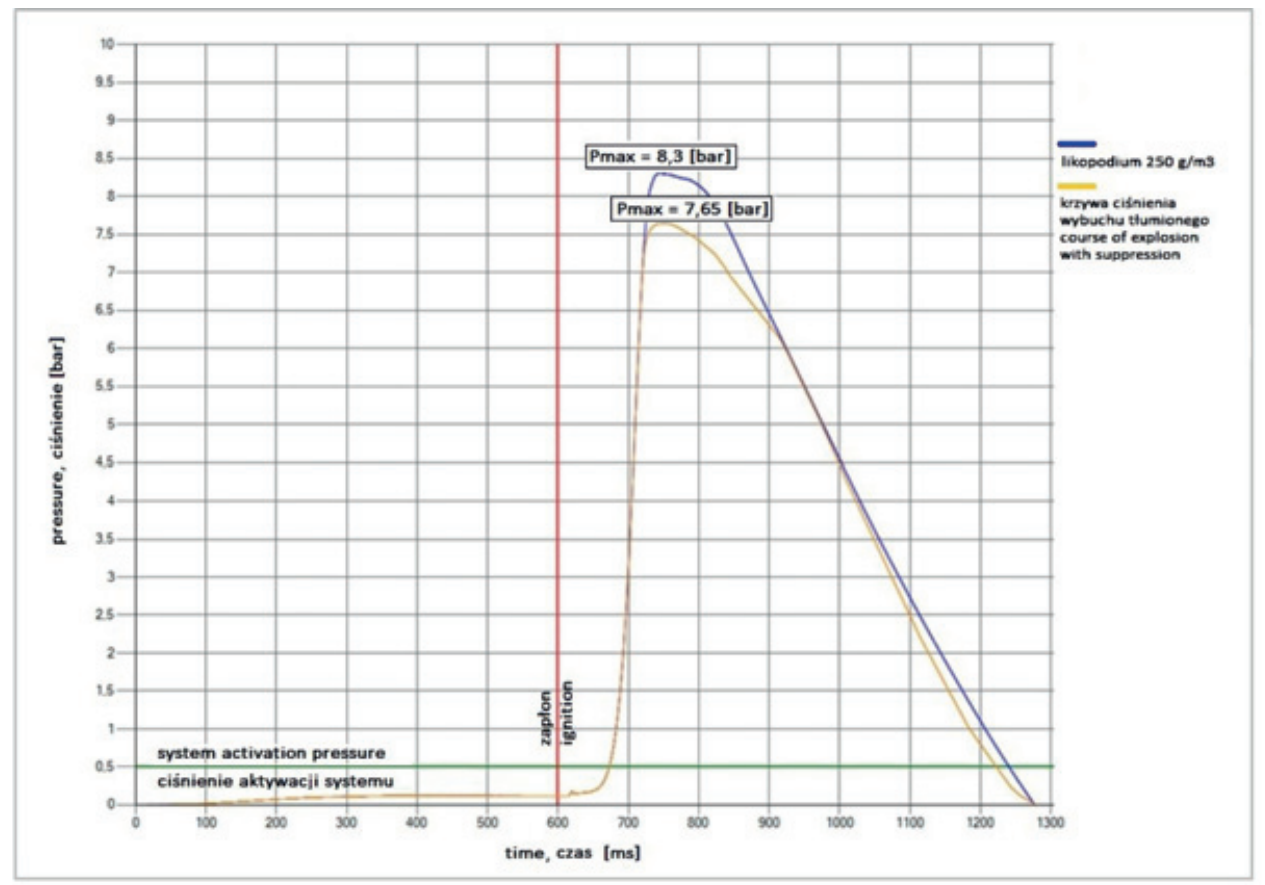

Figure 12. Reduction of explosion pressure at the concentration of combustible dust lycopodium $250 \mathrm{~g} / \mathrm{m}^{3}$

Rycina 12. Redukcja ciśnienia wybuchu przy stężeniu pyłu palnego likopodium $250 \mathrm{~g} / \mathrm{m}^{3}$

Source: Own elaboration.

Źródło: Opracowanie własne.

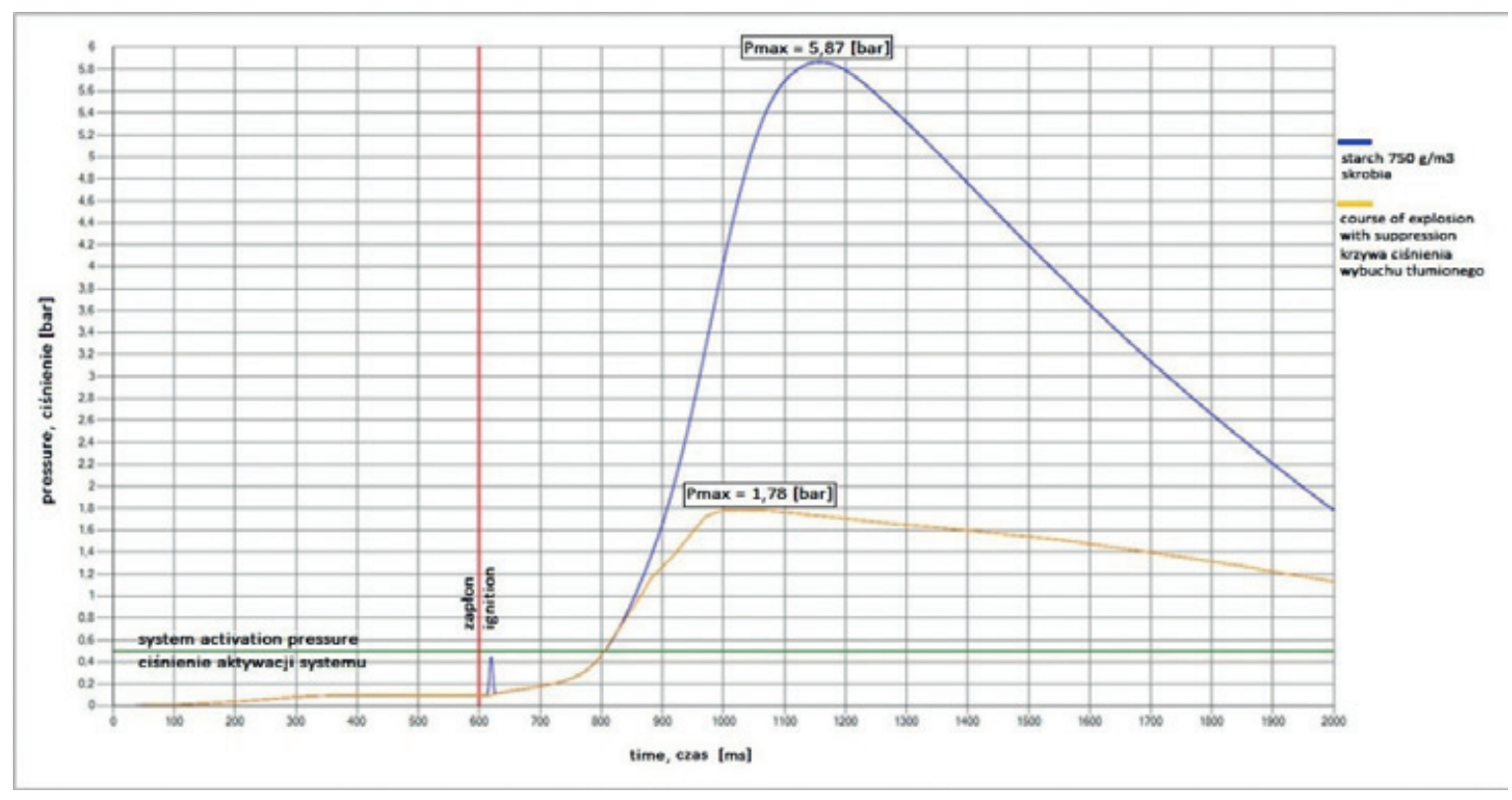

Figure 13. Reduction of explosion pressure at the concentration of combustible dust lycopodium $500 \mathrm{~g} / \mathrm{m}^{3}$

Rycina 13. Redukcja ciśnienia wybuchu przy stężeniu pyłu palnego lycopodium $500 \mathrm{~g} / \mathrm{m}^{3}$

Source: Own elaboration.

Źródło: Opracowanie własne. 
Test No. 3. Suppression of the explosion of starch dust at a concentration of $750 \mathrm{~g} / \mathrm{m}^{3}$

The test was repeated three times for a given dust concentration. A starch and air mixture at a dust concentration of $750 \mathrm{~g} / \mathrm{m}^{3}$ was tested. Such parameters allowed a decrease in pressure from $P_{\text {ex }}=5.87$ bar to $P_{\text {red }}=1.78$ bar. After exceeding the activation pressure of 0.5 bar (after $t \sim 810 \mathrm{~ms}$ ), the HRD extinguisher was activated. The extinguishing powder was discharged into the $1 \mathrm{~m}^{3}$ volume of the tank. Over the next $30-40 \mathrm{~ms}$ a considerable part of the powder was ejected into the tank, forming a mixture suppressing the explosion. In this stage the dust explosion was progressing very slowly in comparison to lycopodium. After 30-40 ms the temporary pressure value of 1 bar was reached and the pressure increase rate $(d p / d t)$ did not reach the maximum value ( $27 \mathrm{bar} / \mathrm{s})$. The explosion was developing at a low rate. The small volume of the tank, combined with the relatively low (in relation to the lycopodium dust explosion) rate of pressure increase $(d p / d t)$ allowed the early application of extinguishing powder. As a result, the extinguishing effect was very strong. As shown in the presented chart (fig. 14), the reduced pressure has a low value (1.78 bar) in comparison to the maximum explosion pressure (5.87 bar).
Test $\mathrm{nr}$ 3. Tłumienie wybuchu pyłu skrobi w stężeniu $750 \mathrm{~g} / \mathrm{m}^{3}$

Test powtórzono trzykrotnie dla danego stężenia pyłu. Badaniu poddano mieszaninę pyłu skrobi z powietrzem - stężenie pyłu $750 \mathrm{~g} / \mathrm{m}^{3}$. Takie parametry zapewniły zredukowanie ciśnienia z $P_{e x}=5,87$ bar do $P_{\text {red }}=1,78$ bar. Po przekroczeniu ciśnienia aktywacji 0,5 bar (po czasie t $\sim 810 \mathrm{~ms}$ ) uruchomiona została gaśnica HRD. Nastąpiło wyładowanie proszku gaśniczego do przestrzeni zbiornika $1 \mathrm{~m}^{3}$. W ciągu kolejnych 30-40 ms duża część proszku została wprowadzona do zbiornika i utworzyła mieszaninę gaszącą wybuch. W tej fazie wybuch pyłu rozwijał się bardzo wolno w porównaniu do likopodium. Po 30-40 ms osiągnął chwilową wartość ciśnienia 1 bar, a prędkość wzrostu ciśnienia $(d p / d t)$ nie osiągnęła jeszcze wartości maksymalnej ( 27 bar/s). Wybuch rozwijał się z niską prędkością. Niewielka objętość zbiornika w połączeniu ze stosunkowo (w relacji do wybuchu pyłu likopodium) niewielką prędkością narastania ciśnienia $(d p / d t)$ pozwoliły na podanie proszku gaśniczego odpowiednio wcześnie. Dzięki temu efekt gaszenia był bardzo silny. Jak widać na prezentowanym wykresie (ryc. 14) ciśnienie zredukowane osiąga niską wartość ( 1,78 bar) w porównaniu do maksymalnego ciśnienia wybuchu (5,87 bar).

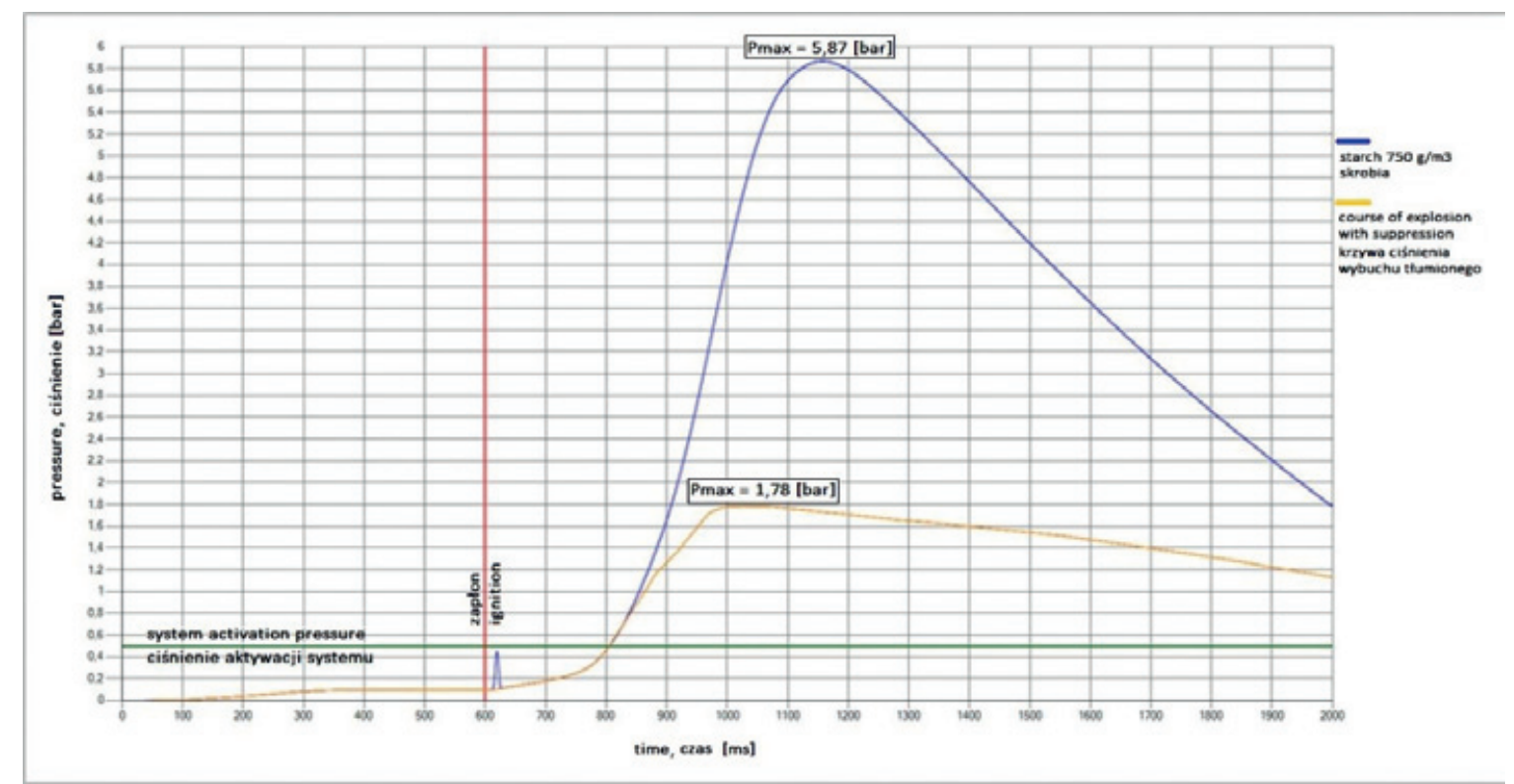

Rycina 14. Redukcja ciśnienia wybuchu przy stężeniu pyłu palnego skrobi $750 \mathrm{~g} / \mathrm{m}^{3}$

Figure 14. Reduction of explosion pressure at the concentration of combustible dust of starch $750 \mathrm{~g} / \mathrm{m}^{3}$

Source: Own elaboration.

Źródło: Opracowanie własne.

Test No. 4. Suppression of the explosion of starch dust at a concentration of $1500 \mathrm{~g} / \mathrm{m}^{3}$

The test was repeated three times for a given dust concentration. A starch and air mixture at a dust concentration of $1500 \mathrm{~g} / \mathrm{m}^{3}$ was tested. Such parameters allowed a decrease in pressure from $P_{e x}=7.4$ bar to $P_{\text {red }}=1.88$ bar. After exceeding the activation pressure of 0.5 bar (after $t \sim 750 \mathrm{~ms}$ ), the HRD extinguisher was activated. The extinguishing powder was discharged into the $1 \mathrm{~m}^{3}$
Test nr 4. Tłumienie wybuchu pyłu skrobi w stężeniu $1500 \mathrm{~g} / \mathrm{m}^{3}$

Test powtórzono trzykrotnie dla danego stężenia pyłu. Badaniu poddano mieszaninę pyłu skrobi z powietrzem - stężenie pyłu $1500 \mathrm{~g} / \mathrm{m}^{3}$. Takie parametry zapewniły zredukowanie ciśnienia z $P_{e x}=7,4$ bar do $P_{\text {red }}=1,88$ bar. Po przekroczeniu ciśnienia aktywacji 0,5 bar (po czasie t $\sim 750 \mathrm{~ms}$ ) uruchomiona została gaśnica HDR. Nastąpiło wyładowanie proszku gaśniczego do przestrzeni zbiornika $1 \mathrm{~m}^{3}$. W ciągu kolejnych 30-40 ms duża 
volume of the tank. Over the next $30-40$ ms a considerable part of the powder was ejected into the tank, forming a mixture suppressing the explosion. In this stage the dust explosion was developing at a very low rate in comparison to lycopodium and faster than for the starch concentration of $750 \mathrm{~g} / \mathrm{m}^{3}$. After $30-40 \mathrm{~ms}$ the temporary pressure value of $\sim 1.2$ bar was reached and the pressure increase rate $(\mathrm{dp} / \mathrm{dt})$ did not reach the maximum value ( $59 \mathrm{bar} / \mathrm{s})$. The explosion developed very slowly. The small volume of the tank, combined with the relatively low (in relation to the lycopodium dust explosion) rate of pressure increase (dp/ $\mathrm{dt}$ ) allowed the early application of extinguishing powder. Due to this the extinguishing effect was very strong. As shown in the presented chart (fig. 15), the reduced pressure has a very low value (1.88 bar) in comparison to the maximum explosion pressure ( 7.4 bar). część proszku została wprowadzona do zbiornika i utworzyła mieszaninę gaszącą wybuch. W tej fazie wybuch pyłu rozwijał się bardzo wolno w porównaniu do likopodium i szybciej w niż przy koncentracji skrobi $750 \mathrm{~g} / \mathrm{m}^{3}$. Po 30-40 ms ciśnienie osiągnęło chwilową wartość $~ 1,2$ bar, a prędkość wzrostu ciśnienia (dp/dt) nie osiągnęła jeszcze wartości maksymalnej ( 59 bar/s). Wybuch rozwijał się bardzo wolno. Niewielka objętość zbiornika w połączeniu ze stosunkowo (w relacji do wybuchu pyłu likopodium) niewielką prędkością narastania ciśnienia (dp/dt) pozwoliły na podanie proszku gaśniczego odpowiednio wcześnie. Dzięki temu efekt gaszenia był bardzo silny. Jak widać na prezentowanym wykresie (ryc. 15), ciśnienie zredukowane ma bardzo niską wartość (1,88 bar) w porównaniu do maksymalnego ciśnieniu wybuchu (7,4 bar).

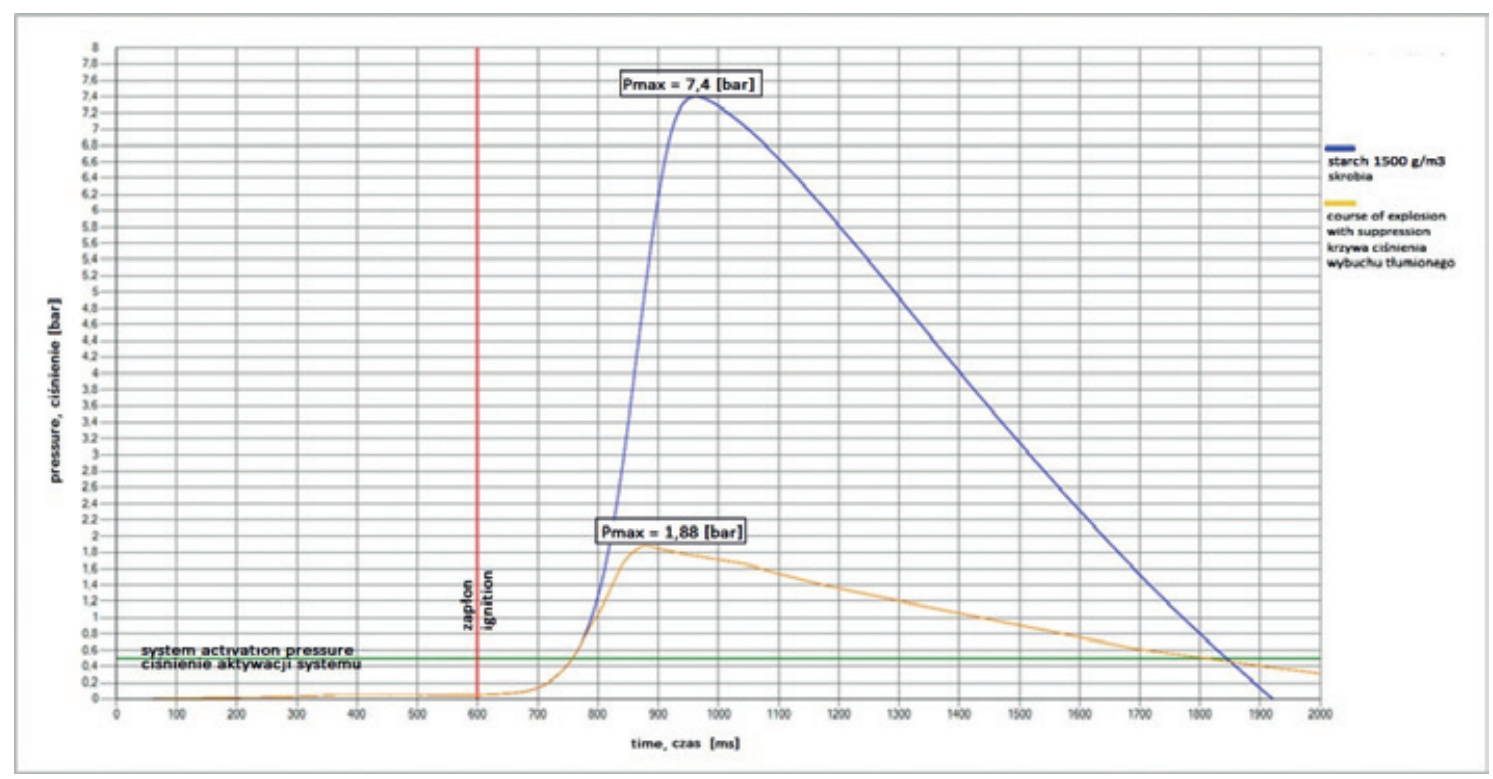

Figure 15. Reduction of explosion pressure at the concentration of combustible dust of starch $1500 \mathrm{~g} / \mathrm{m}^{3}$

Rycina 15. Redukcja ciśnienia wybuchu butlą HRD w stężeniu pyłu palnego skrobi $1500 \mathrm{~g} / \mathrm{m}^{3}$

Source: Own elaboration.

Źródło: Opracowanie własne.

\section{Discussion of methods and results}

Taking into account the obtained results with the applied test equipment configuration, it can be concluded that the system becomes fully effective for dust types characterised by low pressure increase values, i.e. mainly St 1 class dust for the lower pressure increase range. The share of dust types with such parameters is about $80 \%$. An extreme case is lycopodium dust, which is between St1 and St2 classes, i.e. has a high value of pressure increase in time. For such dust, the assumed configuration of the extinguishing system is not as effective as expected, i.e. it is not possible to obtain a strong reduction of explosion pressure. The low volume of the test equipment and the ignition source used certainly contribute to this result. Due

\section{Dyskusja nad metodami i wynikami}

Mając na uwadze uzyskane wyniki przy zastosowanej konfiguracji urządzenia badawczego, można stwierdzić, że system uzyskuje pełną skuteczność dla pyłów charakteryzujących się niską wartością przyrostu ciśnienia, tj. głównie pyłów w klasie St1 dla dolnego zakresu przyrostu ciśnienia. Udział pyłów o takich parametrach wynosi ok. 80\%. Skrajnym przykładem pyłu jest likopodium, który praktycznie znajduje się na granicy klas St1 i St2, tj. charakteryzuje się wysoką wartością przyrostu ciśnienia w czasie. Dla takich pyłów zaproponowana konfiguracja systemu gaśniczego nie wykazuje zakładanej skuteczności, tj. nie można uzyskać silnej redukcji ciśnienia wybuchu. Z pewnością na taki wynik ma wpływ niewielka objętość aparatu badawczego oraz 
to this, there is very little time to suppress the explosion after it is detected in comparison to dust types with low pressure increase values, despite the very short activation times of the extinguishing system. This can also be explained in another way. For a volume limited to $V_{\text {ogr. }}>1 \mathrm{~m}^{3}$ the same explosion will have a greater distance to cover. This will translate into an increase in system effectiveness, as the larger volume would be made inert with the use of an extinguishing medium. An additional effect that can improve the response of the extinguishing system to explosions of dust types with high pressure increase values, is the possibility of changing the location of explosion detection or even increasing the number of sensors to select the optimum layout.

\section{Summary and conclusions}

Explosion suppression using the HRD extinguishing system involves stopping the combustion process inside the protected area. An effective suppression system should interrupt the developing explosion in such a way as to prevent the damage to the protected device caused by an increase in pressure (and also temperature - the secondary effect of the explosion). The suggested tests of HRD system performance involve determining the explosive parameters, i.e. $P_{\max }$ and $(d p / d t)_{\max }$ of the specific dust and then repeating the test with the use of the extinguishing system.

The conducted tests lead to the conclusion that the presented HRD system is characterised by an appropriate level of fire extinguishing performance for dust types with $\mathrm{K}_{\mathrm{st}} \leq 100 \mathrm{bar} \cdot \mathrm{m} / \mathrm{s}$. For potato starch dust, despite the increase in the said value, the system exhibits a constant performance in reducing pressure to the value of $P_{\text {red }}<2$ bar, which can be regarded as a highly satisfactory result. It should also be mentioned that the mechanical components used in the system, which were subjected to loads, are characterised by a high mechanical strength. As a result, further studies will not require frequent maintenance work, which is another proof of the high quality of the developed system.

Due to the limited volume of the test chamber $\left(1 \mathrm{~m}^{3}\right)$, further work on assessing the effectiveness of explosion suppression using an active system will involve:

- performing tests of the extinguishing system using dust with an increasing pressure growth value $(d p / d t)_{\text {max }}$

- using various locations of the ignition source and changing the ignition source,

- determining extinguishing performance for constant explosive parameters of a given dust type as a function of pressure and extinguishing powder mass,

- actions aimed at reducing the detection threshold by eliminating the effect of a pressure surge generated at the moment of injecting dust to the test chamber. zastosowane źródło zapłonu. Skutkuje to tym, że od momentu wykrycia wybuchu do jego ugaszenia jest bardzo mało czasu w porównaniu do pyłów o niskich wartościach przyrostu ciśnienia, pomimo bardzo krótkich czasów zadziałania systemu gaśniczego. Można to także wyjaśnić w inny sposób. Mianowicie w przypadku objętości ograniczonej o $V_{\text {ogr }}$ > $1 \mathrm{~m}^{3}$ taki sam wybuch będzie miał większą drogę do przebycia. Będzie to skutkować tym, że efektywność systemu zwiększy się, ponieważ większa kubatura zostanie zinertyzowana środkiem gaśniczym. Dodatkowym efektem, który mógłby poprawić reakcję systemu gaśniczego w przypadku wybuchów pyłów o wysokiej wartości przyrostu ciśnienia, jest możliwość zmiany lokalizacji detekcji wybuchu lub wręcz zwiększenia liczby czujników w celu doboru optymalnego układu.

\section{Podsumowanie i wnioski}

Tłumienie wybuchu przy pomocy systemu gaśniczego HRD polega na zatrzymaniu procesu spalania w obszarze chronionym. Skuteczny system tłumiący powinien przerwać rozwijający się wybuch tak, aby nie doszło do uszkodzenia zabezpieczanego urządzenia wskutek wzrostu ciśnienia (a także temperatury - oddziaływanie wtórne skutków wybuchu). Zaproponowane badania skuteczności działania systemu HRD polegają na wyznaczeniu parametrów wybuchowości, tj. $P_{\max } \mathrm{i}(d p / d t)_{\max }$ określonego pyłu, a następnie powtórzenia badań z zastosowaniem gaszenia.

Na podstawie przeprowadzonych badań można stwierdzić, że zaprezentowany system HRD charakteryzuje się właściwym poziomem skuteczności gaśniczej w przypadku pyłów o $\mathrm{K}_{\mathrm{st}} \leq 100 \mathrm{bar} \cdot \mathrm{m} / \mathrm{s}$. Dla pyłu skrobi ziemniaczanej - mimo wzrostu ww. wartości - system wykazuje stałą skuteczność w kwestii redukcji ciśnienia do wartości $P_{\text {red }}<2$ bar, co można uznać za bardzo zadowalający efekt. Należy także wspomnieć, że układy mechaniczne zastosowane w systemie, które zostały poddane obciążeniom, charakteryzują się dużą wytrzymałością mechaniczną na uszkodzenia. Dzięki temu dalsze badania nie będą wymagać częstych prac konserwacyjnych, co również przekłada się na wysoką jakość opracowanego systemu.

Z uwagi na ograniczoną objętość zastosowanej komory badawczej $\left(1 \mathrm{~m}^{3}\right)$ dalsze prace nad oceną skuteczności tłumienia wybuchów przy pomocy systemu aktywnego będą ukierunkowane na:

- testy systemu gaśniczego z zastosowaniem pyłów o wzrastającej wartości przyrostu ciśnienia $(d p / d t)_{\text {max' }}$

- zastosowanie różnego położenia źródła zapłonu oraz wraz ze zmianą źródła zapłonu,

- oznaczenie skuteczności gaśniczej dla stałych parametrów wybuchowych określonego pyłu w funkcji ciśnienia oraz masy proszku gaśniczego,

- działania zmierzające do obniżenia progu zadziałania progu detekcji poprzez wyeliminowanie wpływu skoku ciśnienia tworzącego się w momencie wtrysku pyłu do komory badawczej. 


\section{Literature / Literatura}

[1] Moore P.E., Suppressants for the control of industrial explosions, “Journal of Loss Prevention in the Process Industries" 1996, 9, 1, 119-123, https://doi.org/10.1016/0950-4230(95)00045-3.

[2] Taveau J., Vingerhoets J., Suppression of metal dust deflagrations, „Journal of Loss Prevention in the Process Industries” 2015, 36, 244-251, https://doi.org/10.1016/j.jlp.2015.02.011.

[3] Sun Y., Yuan B., Chen X., Li K., Wang L., Yun Y., Fan A., Suppression of methane/air explosion by kaolinite-based multi-component inhibitor, „Powder Technology" 2019, 343, 279-286, https://doi.org/10.1016/j. powtec.2018.11.026.

[4] Song Y., Zhang Q., Quantitative research on gas explosion inhibition by water mist, „Journal of Hazardous” 2019, 363, 16-25, https://doi. org/10.1016/j.jhazmat.2018.09.059.

[5] Oleszczak P., Klemens R., Mathematical modelling of dust-air mixture explosion suppression, „Journal of Loss Prevention in the Process Industries" 2006, 19(2-3), 187-193, https://doi.org/10.1016/j. jlp.2005.05.013

[6] Wang B., Rao Z., Xie Q., Wolański P., Rarata G., Brief review on passive and active methods for explosion and detonation suppression in tubes and galleries, „Journal of Loss Prevention in the Process Industries” 2017, 49, Part B, 280-290, https://doi.org/10.1016/j.jlp.2017.07.008.

[7] Klemens R., Szatan B, Gieras M., Wolański P., Maranda P., inni, Suppression of dust explosions by means of different explosive charges, "Journal of Loss Prevention in the Process Industries" 2000, 13, 265-275, https://doi.org/10.1016/s0950-4230(99)00050-9.

[8] Klemens R., Gieras M., Kalużny M., Dynamics of dust explosions suppression by means of extinguishing powder in various industrial conditions, ,Journal of Loss Prevention in the Process Industries" 2007, 20,664-674, https://doi.org/10.1016/j.jlp.2007.04.021.
[9] Gieras M., Klemens R., Effectiveness of an active dust and gas explosion suppression system, „Journal of Power Technologies” 2012, 92 (1), 1-11.

[10] Barton J., Dust explosion prevention and protection: A practical guide, Gulf Professional Publishing 2002, https://doi.org/10.1021/ op020041a.

[11] Eckhoff R. K., Dust explosions in the process industries, Elsevier Science, 2003.

[12] Bartknecht W., Explosions, Course, prevention, protection, Springer Verlag, Berlin - Heidelberg - New York 1981.

[13] Bartknecht W., Dust explosions, Course, prevention, protection, Springer Verlag, Berlin - Heidelberg - New York 1989.

[14] Cross J., Farrer D., Dust explosions, Plenum Press, New York 1982, https://doi.org/10.1007/978-1-4615-6869-8_7.

[15] Eckhoff K., Dust explosions in the process industries, 3-th edition, Elsevier Science, 2003, https://doi.org/10.1016/b978-0750676021/50003-2.

[16] Abbasi A., Dust Explosions-Cases, causes, consequences and control, Center for Pollution Control and Energy Technology, Pondicherry University, Pondicherry 605014, India, 2006.

[17] Siwek R., 2nd WORLD SEMINAR on the Explosion Phenomenon and on the Application of Explosion Protection Techniques in Practice, European Institute for Explosion Safety and Related Risks, 1996.

[18] PN-EN 14034-1+A1:2011 - Oznaczanie charakterystyk wybuchowości obłoków pyłu. Część 1: Oznaczanie maksymalnego ciśnienia wybuchu $\mathrm{P}_{\max }$ obłoków pyłu.

[19] PN-EN 14034-2+A1:2011 - Oznaczanie maksymalnej szybkości narastania ciśnienia wybuchu (dp/dt) ${ }_{\max }$ obłoków pyłu.

[20] PN-EN 14373:2006 - Systemy tłumienia wybuchu. 
JUNIOR BRIG. PIOTR LESIAK, M.SC. ENG. - He graduated from the Main School of Fire Service in Warsaw in 2002. A graduate of engineering studies in Chemistry at the Military University of Technology, he completed his post-graduate studies in Business Process Safety at the Lodz University of Technology. He works at the Scientific and Research Centre for Fire Protection - National Research Institute in Józefów as a senior specialist at the Laboratory of Combustion Processes and Explosions.

DAMIAN BĄK, ENG. - In 2013 he graduated from the Faculty of Production Engineering of the Warsaw University of Technology in the field of Mechanics and Machine Design. He is currently finishing his MSc studies in the field of Management and Globalised Production Engineering at the same university. He is currently a specialist at the Laboratory of Combustion Processes and Explosions at the Scientific and Research Centre for Fire Protection - National Research Institute in Józefów.

BRIG. DANIEL MAŁOZIĘĆ, M.SC. ENG. - He graduated from the Main School of Fire Service in Warsaw. He is currently the Head of the Laboratory of Combustion Processes and Explosions at the Scientific and Research Centre for Fire Protection - National Research Institute in Józefów. Specialisation - combustion processes.

MARCIN GRABARCZYK, PH.D. ENG. - A graduate of the Faculty of Power and Aeronautical Engineering at the Warsaw University of Technology, former employee of the Scientific and Research Centre for Fire Protection - National Research Institute and the Institute of Aviation. He is currently in charge of patent procedures, commercialisation, product development in cybersecurity, and R\&D project management at NASK- National Research Institute.

ANDRZEJ KOŁACZKOWSKI, M.SC. ENG. - A graduate of the Warsaw University of Technology with over 30 years' professional experience. Director and head of the design team at ANKO, a company specialising in the construction of highly advanced measurement devices and test stations. Expert and advisor for international research and certification bodies, including TUV SUD.Author of multiple patents and over 100 designs of devices deployed to production.
Mt. BRYG. MGR INŻ. PIOTR LESIAK - W 2002 r. ukończył studia w Szkole Głównej Służby Pożarniczej w Warszawie. Absolwent studiów inżynierskich na kierunku chemia w Wojskowej Akademii Technicznej oraz studiów podyplomowych Bezpieczeństwo Procesów Przemysłowych na Politechnice Łódzkiej. Pełni służbę w Centrum Naukowo-Badawczym Ochrony Przeciwpożarowej PIB w Józefowie na stanowisku starszego specjalisty w Zespole Laboratoriów Procesów Spalania i Wybuchowości.

INŻ. DAMIAN BĄK - W 2013 r. ukończył studia na Wydziale Inżynierii Produkcji Politechniki Warszawskiej, kierunek Mechanika i Budowa Maszyn, obecnie kończy studia magisterskie na kierunku Zarządzaniei Inżynieria Produkcji Zglobalizowanej tej samej uczelni. Pracujena stanowisku specjalisty w Zespole Laboratoriów Procesów Spalania i Wybuchowości w Centrum Naukowo-Badawczym Ochrony Przeciwpożarowej - PIB w Józefowie.

BRYG. MGR INŻ. DANIEL MAŁOZIĘĆ - Absolwent Szkoły Głównej Służby Pożarniczej w Warszawie. Obecnie kierownik Zespołu Laboratoriów Procesów Spalania i Wybuchowości w Centrum NaukowoBadawczym Ochrony Przeciwpożarowej PIB w Józefowie. Specjalność - procesy spalania.

DR INŻ. MARCIN GRABARCZYK - Absolwent Wydziału Mechanicznego Energetyki i Lotnictwa Politechniki Warszawskiej, były pracownik CNBOP-PIB oraz Instytutu Lotnictwa. Obecnie w NASK-PIB zajmuje się procesami patentowymi, komercjalizacją oraz rozwojem produktów z zakresu cyberbezpieczeństwa, a także zarządzaniem projektami typu B+R.

MGR INŻ. ANDRZEJ KOŁACZKOWSKI - Absolwent Politechniki Warszawskiej z ponad 30 letnim doświadczeniem zawodowym. Dyrektor i szef zespołu projektantów firmy ANKO specjalizującej się w budowie zaawansowanych urządzeń pomiarowych i stanowisk badawczych. Ekspert i konsultant międzynarodowych instytucji badawczych i certyfikacyjnych w tym TUV SUD. Autor patentów i ponad 100 projektów wdrożonych do produkcji urządzeń. 